\title{
Coated Metal Powders for Laser Powder Bed Fusion (L-PBF) Processing: A Review
}

\author{
Robert Bidulsky ${ }^{1, *(\mathbb{D})}$, Federico Simone Gobber ${ }^{2} \mathbb{D}$, Jana Bidulska ${ }^{3} \mathbb{D}$, Marta Ceroni $^{2}$, Tibor Kvackaj $^{3}$ and $^{-}$ \\ Marco Actis Grande 2,4 (D) \\ 1 Asian Innovation Hub, Budulov 174, 04501 Moldava nad Bodvou, Slovakia \\ 2 Department of Applied Science and Technology (DISAT), Politecnico di Torino, Viale T. Michel 5, \\ 15121 Alessandria, Italy; federico.gobber@polito.it (F.S.G.); marta.ceroni@polito.it (M.C.); \\ marco.actis@polito.it (M.A.G.) \\ 3 EPMA PM R\&D Centre, Faculty of Materials, Metallurgy and Recycling, Technical University of Kosice, \\ Park Komenskeho 10, 04001 Kosice, Slovakia; jana.bidulska@tuke.sk (J.B.); tibor.kvackaj@tuke.sk (T.K.) \\ 4 Consorzio Consorzio Interuniversitario Nazionale per la Scienza e Tecnologia dei Materiali (INSTM), \\ Via G. Giusti 9, 50121 Firenze, Italy \\ * Correspondence: robert.bidulsky@asihub.org
}

Citation: Bidulsky, R.; Gobber, F.S.; Bidulska, J.; Ceroni, M.; Kvackaj, T.; Grande, M.A. Coated Metal Powders for Laser Powder Bed Fusion (L-PBF) Processing: A Review. Metals 2021, 11, 1831. https://doi.org/10.3390/ met11111831

Academic Editor: Sergey N. Grigoriev

Received: 15 October 2021

Accepted: 10 November 2021

Published: 14 November 2021

Publisher's Note: MDPI stays neutral with regard to jurisdictional claims in published maps and institutional affiliations.

Copyright: (c) 2021 by the authors. Licensee MDPI, Basel, Switzerland. This article is an open access article distributed under the terms and conditions of the Creative Commons Attribution (CC BY) license (https:// creativecommons.org/licenses/by/ $4.0 /)$.

\begin{abstract}
In the last years, functionalized powders are becoming of increasing interest in additive manufacturing (particularly in laser powder bed fusion processing, L-PBF), due to their improved flowability and enhanced processability, particularly in terms of laser absorbance. Functionalized powders may also provide higher final mechanical or physical properties in the manufactured parts, like an increased hardness, a higher tensile strength, and density levels close to theoretical. Coatings represent a possible interesting approach for powders' functionalizing. Different coating methods have been studied in the past years, either mechanical or non-mechanical. This work aims to present an overview of the currently obtained coated powders, analyzing in detail the processes adopted for their production, the processability of the coated systems, and the mechanical and physical properties of the final parts obtained by using L-PBF for the powders processing.
\end{abstract}

Keywords: coated metal powders; absorbance; L-PBF; mechanical and physical properties

\section{Introduction}

Manufacturing techniques based on powder metallurgy (PM) play a significant role in several different industrial fields including, among others, automotive [1,2], aerospace [3-5], and biomedical [6,7]. PM is also growing in the production of electro-magnetic components with properties difficult or impossible to be obtained with conventional forming techniques [8-11].

The necessity of obtaining more performing PM parts led to the development of functionalized base materials [12-14] and optimized processes. In this frame, the use of coated powders has been significantly increasing in PM, aiming to improve the powders' processability or to modify the final part's microstructural, mechanical, physical, and thermal properties. By coating the powders' surface, it is possible to change melting temperatures [15], the flowability [15,16], and the absorbance [17-21] of the powder itself. Microstructural characteristics can also be modified by coating with a second phase, particularly nanoceramic particles such as $\mathrm{ZrO}_{2}, \mathrm{Al}_{2} \mathrm{O}_{3}, \mathrm{~B}_{4} \mathrm{C}, \mathrm{SiC}, \mathrm{TiB}_{2}, \mathrm{C}$-based structures [22-24]. These can induce grain refinement mechanisms, thus enhancing the mechanical strength $[15,23]$. Mechanical properties of the final parts, such as compressive strength $[25,26]$, hardness $[15,26,27]$, yield strength $[15,28]$, and physical properties like density $[19,29]$, are improvable by adopting coated powders.

Additive manufacturing (AM) represents a challenging topic for researchers, as demonstrated by the increasing number of industrial applications in several different sectors [30]. 
AM processes are classified after DIN EN ISO/ASTM 52900 standard [31]. They represent an alternative to subtractive and formative manufacturing [32]. In particular, laser powder bed fusion (L-PBF) is suitable for obtaining complex metallic objects owing to its geometric freedom when selectively sintering the powders [33-35]. L-PBF is a layer-by-layer process where a laser beam is applied to melt the metal powders selectively; the molten layer then solidifies at a high cooling rate [36-40]. Adopting a laser source implies using metal powders characterized by a proper laser absorptivity [41,42]. Poor absorbance causes many defects such as pores, low-quality surfaces, and un-melted powder in the 3D-printed parts [41,43-46].

Concerning the materials processable by L-PBF, beyond pure metals and alloys, also intermetallic-based compounds can be printed to obtain dense parts [47-49]. The possibility of integrating more parts into an assembly [37,38], obtaining high-density parts [50], and having low material wastage [45,49], are some of the further advantages provided by L-PBF. In order to guarantee uniform distribution of the powders in each layer, powders used for L-PBF should be characterized by good flowability and spherical morphology [36,51-53].

L-PBF printed parts can be post-treated with hot isostatic pressing (HIP) technique $[54,55]$. HIP removes residual stresses, promotes grain growth and recrystallization [56], improves mechanical properties, particularly creep and fatigue resistance $[57,58]$. In addition, HIP can reduce porosity generated during the previous process, as demonstrated with steels [59], $\mathrm{Ti}$ [60], and also $\mathrm{Al}[61]$ ingots obtained from casting.

Coated powders are adopted in the L-PBF process both for improving their processability (especially for increasing the laser absorptivity and powders' flowability) and/or the properties of the final parts. For increasing laser absorptivity, at the emission wavelength of the laser commonly adopted in L-PBF (1064 or $1070 \mathrm{~nm}$ ), an increase of powders' surface roughness can be provided $[62,63]$. Another solution might be coating powders with a material characterized by a lower reflectance [17-19,21,63-65]. Poor flowability of powders can be attributed to the influence of van der Waals (vdW) forces. According to Rumpf [66], the effect of vdW forces can be reduced by adequately tailoring the surface roughness of the powders by coating them with smaller particles [67].

This work presents an overview of the most up-to-date coated systems (powder + coating), including the description of the applied coating methods, in order to analyze and understand not only the potentialities in improving materials' processability through L-PBF (such as improving their absorbance) but also some of the mechanical properties of the final objects.

\section{Base Metal Powders}

Steels powders are widely used in an extensive range of industrial fields such as aerospace [68], automotive [69], oil and gas industries [70], biomedical engineering [7,68,71], and other fields, owing to their high ductility and high strength [72], biocompatibility and, considering stainless steel powders, also to their high corrosion resistance [68,72]. Austenitic stainless steel powders show however low hardness and relatively poor wear resistance; a strategy for improving the hardness and the wear resistance is coating the metal powders using ceramic nanoparticles (e.g., $\mathrm{TiB}_{2}$ ) acting as a grain refiner. Extensive dislocations are introduced too, leading to a finer microstructure and higher mechanical properties [70,72].

Powders of titanium and its alloys are used in many industrial fields like chemical industries [73,74], defense industrial sectors, aerospace $[73,75,76]$, and biomedical applications $[6,75,77]$. This is due to their high specific strength, high biocompatibility, low density, and optimal corrosion resistance [6,73,75,76,78]. However, titanium and its alloys are also characterized by low hardness and relatively poor wear resistance responsible for the limited industrial areas of use, especially for those applications characterized by erosive and abrasive-based wear processes. The addition of ceramic particles can raise the working temperature and the mechanical properties [74,79]. 
Metal powders made of aluminum and its alloys find application in a wide range of fields: aerospace $[5,80]$, automotive $[81,82]$, and domestic industries [80] owing to their lightweight, high specific strength, high corrosion resistance, good thermal conductivity, and good mechanical properties [5,80-82]. Aluminum matrix composites (AMCs) have been adopted to increase wear resistance and hardness. Coating metal powders can produce AMCs with reinforcement particles such as $\mathrm{Al}_{2} \mathrm{O}_{3}$ and $\mathrm{SiC}$ [83-85]; hexaborides such as $\mathrm{CeB}_{6}$ and $\mathrm{LaB}_{6}$ are used as grain refiners in aluminum alloys both in powder metallurgy [86] and in casting and wrought metallurgy [87,88].

Pure copper is widely used for electronic applications [89] and heat transfer components [90] in different sectors like automotive and naval sector [91] due to its excellent solderability and low electrochemical migration [92], superior electrical $\left(58.7 \times 10^{6} \mathrm{~S} / \mathrm{m}\right)$ and thermal conductivity $(400 \mathrm{~W} /(\mathrm{m} \cdot \mathrm{K}))[43,89,90,92]$. Nevertheless, pure copper is soft, so alloying it with $\mathrm{Sn}, \mathrm{Zn}, \mathrm{Cr}$, and $\mathrm{Ni}$ is mandatory for structural applications; these enhance the mechanical properties of copper but reduce its conductivity [93].

\section{Powders Absorptance}

The powders processed by L-PBF must have a good absorbance at the wavelength of 1064-1070 nm. Pure copper and aluminum are characterized by a low laser absorbance at $1070 \mathrm{~nm}[41,42,94]$, as shown in Figure 1 below.

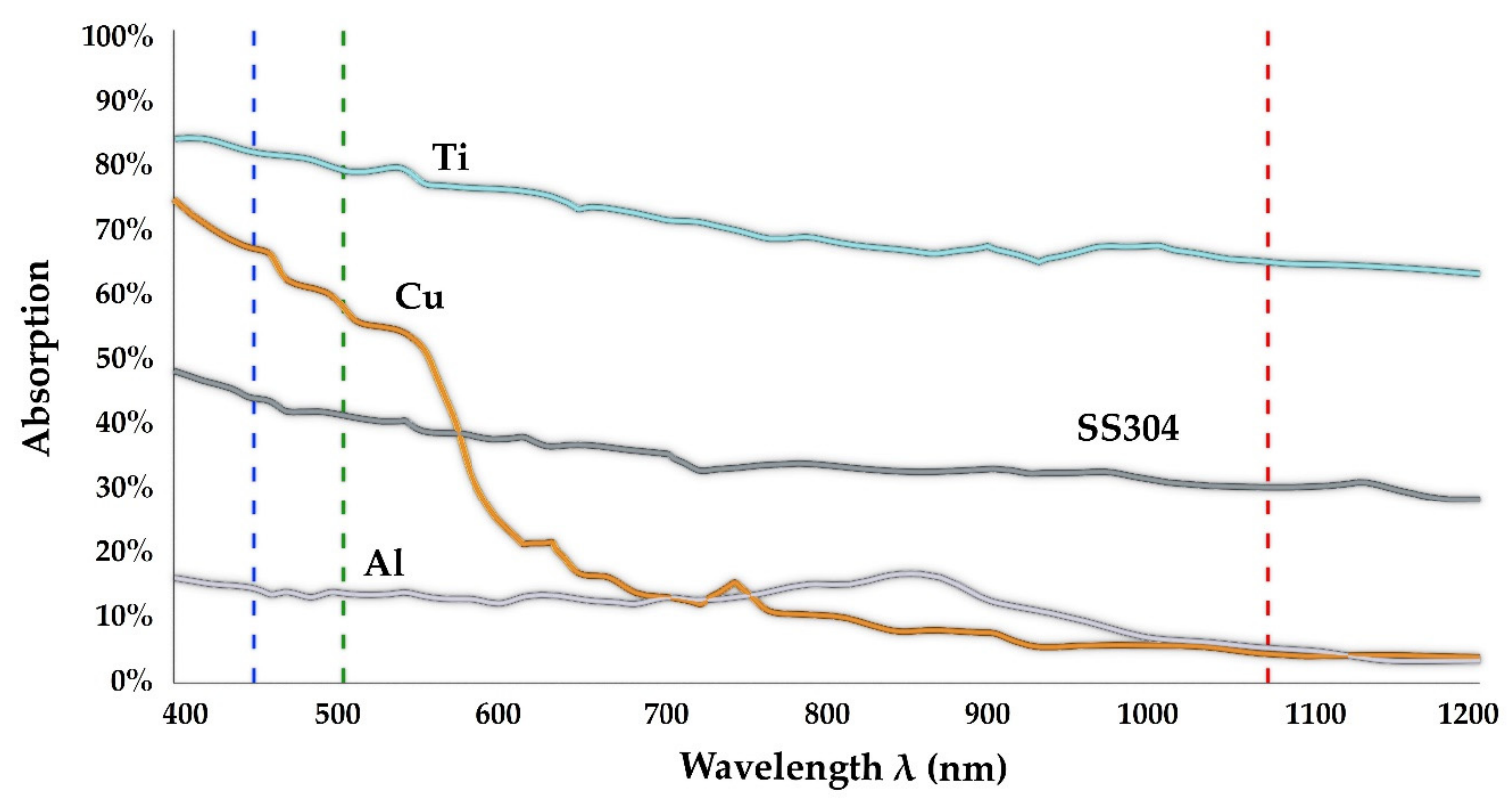

Figure 1. Absorbance vs. wavelength for stainless steel AISI 304, titanium, aluminum, and copper; green, blue, and red laser emission wavelengths are highlighted.

Figure 1 reports the absorbance of stainless steel 304, titanium, aluminum, and copper as function of the wavelength. Ti-based powders show a relative absorbance of about $70 \%$ in the range of 1064-1080 nm (corresponding to the red laser), whereas stainless steels (Figure 1 reports the case of AISI 304) are generally characterized by values around 30-35\%. Copper and aluminum have a significantly lower absorbance in the red laser emission spectrum (below 10\%). Moreover, copper also shows a quite critical absorbance since the energy provided by the laser is quickly dissipated or reflected $[18,21]$. Different approaches have been investigated to solve this problem: the first consists in the adoption of a high power laser $(800-1000 \mathrm{~W})[95,96]$, the second in processing specifically designed alloys characterized by lower thermal conductivity $[97,98]$, the third in substituting the red laser source with a green or blue source (wavelengths of $515 \mathrm{~nm}$ [43] and $450 \mathrm{~nm}$ [99] respectively). At these wavelengths, copper shifts its optical absorption mechanism from the intra-band to the inter-band electronic transition [100]. Another possibility is by coating the powder's 
surface with a different material characterized by a higher absorbance [17-19,21,64,65]. It has been demonstrated that surface oxidation can increase absorbance up to $58 \%$ (from $32 \%$ for pure copper); however, this improvement does not appear to be sufficient for the correct processing of the powder [65]. The absorbance of pure copper powders has also been measured in $[18,20]$, its value ranging between $26 \%$ and $39 \%$.

\section{Coating Processes}

Generally, coating processes consist of depositing particles or ions on metal powders; this target is achievable by mechanical or non-mechanical methods detailed in the article. The non-mechanical methods consist of an extensive range of physical and thermal processes with specific variations. Several processes involving solution, chemical, and physical methods for coating powders have been developed and used to solve some of the critical issues of mechanical coating methods.

\subsection{Mechanical Methods}

\subsubsection{Ball Milling}

Ball milling is a largely diffused technique that allows dispersing particles on metal powders: it is a non-equilibrium process generally operating at low temperatures, with conceptually linear operations, and a low overall cost [101,102]. The optimal control of the results obtained from ball milling is however nontrivial; plenty of variables such as ball size, rotation speed, duration, atmosphere, and process control agents (PCA) have significant effects on its outcomes. PCA acts on powder's purity, grain size, and shape. The ball milling process can be both dry and wet depending on the necessity: in wet ball milling, a solution is added as PCA to reducing the maximum temperature reached during the process [101]. The general scheme of the ball milling process is reported in Figure 2; the metal powders and the coating particles are inserted into a mill containing the balls and the PCA if needed; the balls lead to a faster homogenization, promoting the adhesion of the coating particles to the powder.

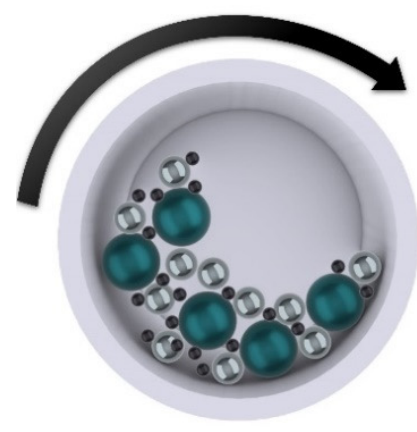

Metal powder
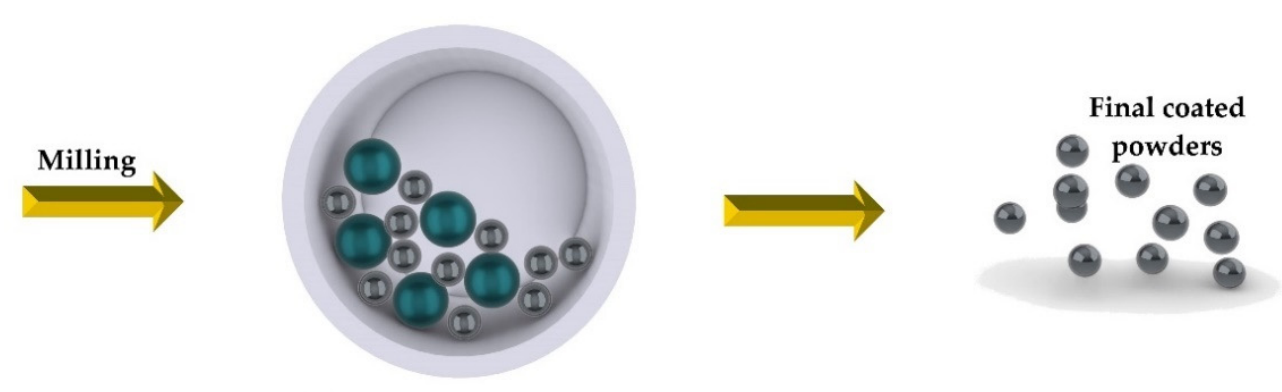

Ball

Figure 2. Schematic diagram of ball milling process for coating powders, the objects in figures are not in scale.

Ball milling is widely adopted for coating metal powders to be used in L-PBF $[22,23,26-29,47,103-113]$ and in hot isostatic pressing (HIP) processes [27,114,115]. According to the energy level, ball milling can be high-energy (HEBM) or low-energy (LEBM). The main differences between the two lie in ball-to-power ratio, mixing speed, and processing time, with all the parameters being higher for HEBM. In particular, the ball-to-powder ratio ranges from 5:1 to 30:1 in HEBM, whereas it is 1:1 in LEBM [105]. HEBM is often coupled to nanoceramic particles $[107,116]$ since they tend to agglomerate due to their high aspect ratio easily. The promotion of strong vdW forces may cause the formation of aggregates leading to microstructural inhomogeneities. HEBM deforms the powders to a 
high degree; indeed, they do not maintain the original spherical morphology, causing a reduction of flowability and making powders less suitable for L-PBF $[29,105,116]$.

On the other hand, after LEBM, powders retain their original spherical morphology $[105,116]$. Zhai et al. [105] report LEBM to effectively coat steel particles with a uniform layer of $\mathrm{Y}_{2} \mathrm{O}_{3}$ nanoparticles. Powders kept their spherical geometry after processing for $7 \mathrm{~h}$, and LEBM determined an increase in surface roughness leading to a slight decrease in flowability, apparent and tap densities.

Attar et al. [26] underlined the importance of milling time. In their study, the influence of milling time on the distribution of $\mathrm{TiB}_{2}$ particles on the powder surface is evaluated: $1 \mathrm{~h}$ is not sufficient to obtain a uniform coating, $4 \mathrm{~h}$ caused an excessive flattering of powders, whereas $2 \mathrm{~h}$ provided both a uniform coating and a suitable geometry. Han et al. [23] focused on the milling time, proposing to interval the milling with pausing steps to reduce the temperature reached by the powders due to the impacts with the balls. They also investigated the introduction of stearic acid lubricant to facilitate the process.

The ball milling process is also used for mechanical alloying (MA) $[117,118]$. HEBM can lead to MA, resulting in a modification of powders' size, microstructure, and morphology. It can synthesize both equilibrium and non-equilibrium alloy phases such as supersaturated solid solutions, nanostructures, metastable crystalline phases, and amorphous alloys. The high collision between powders and balls determinate a mass transfer accelerating the diffusion of elements. Nevertheless, MA is characterized by a large amount of uncertainty on the final microstructure [118]. MA has been adopted in order to cover metal powders $[22,27,47,114]$, which underwent characterization by X-ray diffraction (XRD). Gu et al. [47] investigated Ti powders mixed with graphite and Al nano powders; after $10 \mathrm{~h}$ processing, $\mathrm{C}$ peaks disappeared, while $\mathrm{TiC}$ was detected. A similar trend is obtained with $\mathrm{Al}$ peaks, which gradually disappears during the processing and is not detectable after $20 \mathrm{~h}$ of HEBM. AlMangour et al. [27] coated 316L powders with $\mathrm{TiB}_{2}$ particles ( 2.5 vol.\%). After milling for $2 \mathrm{~h}, \gamma$-Fe peaks were only detected $\left(\mathrm{TiB}_{2}\right.$ was not detected due to the small amount), after milling for $4-8 \mathrm{~h}$ XRD evidenced TiB2 peaks, also $\alpha$-Fe phase was identified, and its peaks intensity increased with milling time, due to the plastic deformation causing $\gamma$-Fe to transform into $\alpha$-Fe. Wang et al. [114] also observed the formation of $\alpha$-Fe and the reduction of $\gamma$-Fe peaks intensity after coating pre-alloyed AISI 304 powders with Ti and $\mathrm{Y}_{2} \mathrm{O}_{3}$. After milling for $15 \mathrm{~h}$, Ti and $\mathrm{Y}_{2} \mathrm{O}_{3}$ were not detectable in the material, while $\mathrm{YO}_{1.401}$ and $\mathrm{Ti}_{3} \mathrm{~N}_{1.29}$ peaks were indexable.

\subsubsection{Turbula}

Turbula proved to be effective in the mechanical coating of metals powders in several studies $[15,16,19,119]$.

The Turbula mechanically mixes powders and coating particles without using balls; as a result, the deformation on the starting metal powders is strongly reduced. This technique has been adopted by Jadhav et al. [19] to coat the copper powders and increase their optical absorption and flowability. By adding $0.1 \mathrm{wt} . \%$ carbon particles, the authors enhanced the optical absorption to $67 \%$, starting from $29 \%$ for pure copper. Moreover, Karg et al. [16] used turbula to add $\mathrm{SiO}_{\mathrm{x}}$ nanoparticles on aluminum alloy powders. The authors increased the powder's flowability leading to an increase in the relative density of the final parts after L-PBF. Hentschel et al. [15] noticed that one of the most influential parameters is milling time; they found that achieving a homogeneous distribution of nanoparticles needed at least $2 \mathrm{~h}$. The flowability of powders is increased by introducing $0.2 \mathrm{wt} . \%$ of nanoparticles; a further increase in the concentration of nanoparticles causes a decrease in flowability but remains acceptable for concentrations lower than $0.5 \mathrm{wt} . \%$. 


\subsection{Non-Mechanical Methods}

\subsubsection{Powders Immersion}

Coating particles are dispersed in a solution into which metal powders are immersed, with a possible variation being the drop by drop addition of coating particles to the powders-containing solution. A general scheme of the process is shown in Figure 3.

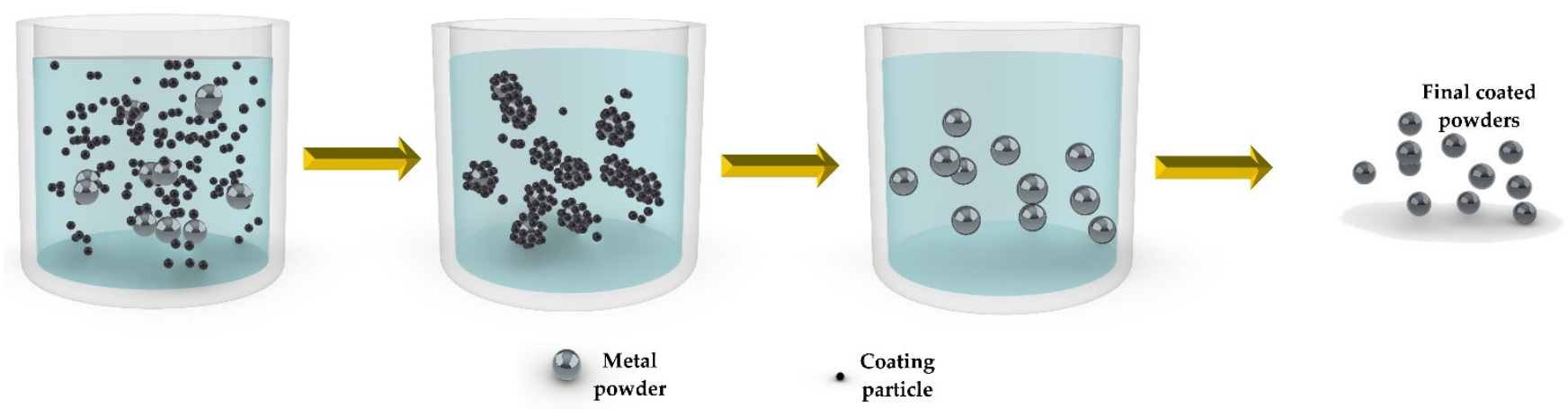

Figure 3. Schematic diagram of coating process involving solution for coating powders, the objects in figures are not in scale.

One coating process through powder immersion involving the use of solutions is electroless plating [120]. This technique is preferred to the electrolytic plating process owing to its lower cost, high efficiency, applicability independently of the shape of the powder, and a dense and uniform coating deposition [121-124] whose thickness depends on the powder morphology. Electroless plating has been used for coating powders in different fields [17,23,122-127]. Li et al. [122] observed that the powder surface became coarse and irregular; some coating clusters were detected, whose formation can be related to the high deposition rate. Intermediate layers may be introduced to improve adhesion, as investigated by $\mathrm{Xu}$ et al. [123]. Sn was used as an intermediate layer between the $\mathrm{Cu}$ powder and the Ag coating then this system was heat treated to form an alloyed transition layer increasing bonding strength and oxidation resistance. The coated powders maintained an excellent dispersion, while their sphericity and surface smoothness decreased marginally. Jadhav et al. [17] deposited a thin layer of $62 \pm 14 \mathrm{~nm}$ of metallic Sn on copper powders; the best results were obtained with a $0.28 \mathrm{wt} . \%$ Sn coating layer that led to an increase in powders flowability and an enhancement from $19 \%$ to $51 \%$ of powders optical absorption. The authors also underlined the importance of using starting powders with low sulfur content, given their critical behavior in L-PBF. Geng et al. [125] homogeneously deposited $\mathrm{Ni}$ onto Al powders. The process led to an increased laser absorbance owing to the Ni lower laser reflectivity and increased surface roughness. In addition, flowability was comparable to that of the starting powder.

Electrostatic self-assembly is another possible way of coating powders. The electrostatic attraction allows to assemble spontaneously metal powders and the coating particles during hetero-agglomeration [128,129]. Electrostatic self-assembly guarantees good flowability and the possibility of depositing structures such as carbon nanotubes (CNTs), preventing their destruction $[62,63,116,128]$. Zhou et al. [116] used CNTs and nano $\mathrm{Al}_{2} \mathrm{O}_{3}$ to coat metal powders. The two nanoparticles are characterized by opposite charges (negative the former and positive the latter), so a CNTs/Al2O3 hybrid was obtained by mixing them. This structure resulted negatively charged since $\mathrm{Al}_{2} \mathrm{O}_{3}$ did not cover all CNTs, leaving some uncovered surface that can bond to the metal powder. The hybrid solution was slowly added to the metal powder colloid and then mechanically stirred. The deriving coated powders are characterized by homogeneous dispersion of the hybrid coating on the metal powders, suitable particle size and distribution, good flowability, and enhanced surface roughness leading to an increased laser absorptivity. In a more recent study Zhou et al. [62] used CNTs for coating titanium alloy powders. The oxidized surface 
of the metal powder is positively charged and, due to the electrostatic attraction, it reacts with CNTs: an increase in the surface roughness has been detected coupled to a consequent increase in laser absorptivity. Dong et al. [63] used graphene oxide sheets to coat Al alloy powders; the coated powders are characterized by a decrease in thermal conductivity and an increase in laser absorptivity.

A suspension characterized by a $\mathrm{pH}$ ranging between the two isoelectric points (IEPs) of two different materials leads to a dielectrophoretic deposition, representing an alternative way of coating powders $[130,131]$. Different studies have adopted coating ferritic steel powders with $\mathrm{Y}_{2} \mathrm{O}_{3}$ nanoparticles [25,131-133]. Before the deposition step, the suspension containing $\mathrm{Y}_{2} \mathrm{O}_{3}$ nanoparticles has been irradiated to de-agglomerate the nanoparticles. The $\mathrm{pH}$ of the suspension is then set to a value able to guarantee that particles and powders are oppositely charged. Finally, the steel powders are added to the suspension, and the $\mathrm{pH}$ controls the adsorption. Thus, the dielectrophoretic deposition is scalable and economically feasible [132].

Other solution-based methods for coating powders are reported in literature [21,56,134-136]. Ma et al. [136] adopted an electro-codeposition process where mechanical mixing and sonication were used to distribute $\mathrm{Al}_{2} \mathrm{O}_{3}$ nanoparticles and maintain dispersion. Metal powders coated by nanoparticles dissipate less laser-transferred heat, thus generating an increase in the melt pool depth. The study also reports a reduced heataffected zone. Garmendia et al. [135] coated an aluminum alloy powder with a 1 wt.\% copper formate-methanol solution; powders were then heat-treated in vacuum, and the copper precursor was reduced to metal copper. This coating process did not particularly affect the size, flowability, and morphology of the powders. Smith et al. [56] used acoustic mixing to coat $\mathrm{NiCoCr}$ powders with $\mathrm{Y}_{2} \mathrm{O}_{3}$ nanoparticles. The acoustic mixing uses a wave that attained a resonance among the container, the powders, and the vibrating spring system [137], providing homogenization of the powder in one hour. Zhang et al. [134] coated aluminum alloy powders with styrene to process them through direct light processing (DLP), a specific AM process requiring the dispersion of powders in a monomer and its photoinitiator $[138,139]$. The necessity of coating aluminum alloy powders before dispersing them into the monomer and in its photoinitiator is related to the agglomeration of fine powders (size $<30 \mu \mathrm{m}$ ), having a high surface-to-volume ratio [140], and to the high refractive index difference between the powders and the photosensitive resin; the latter causing a low light penetration depth. Styrene monomer and its initiator are added to the metal powders. They are stirred and heated to $75^{\circ} \mathrm{C}$; after $6 \mathrm{~h}$, the powders are coated and ready to be mixed with the monomer and its photoinitiator for printing. The coating has a uniform thickness (200-400 nm), and the shape of the powder is not modified by the coating process.

\subsubsection{Chemical Vapor Deposition and Physical Vapor Deposition}

Babul et al. [141] produced graphene-coated $\mathrm{Cu}$ powders using a chemical vapor deposition (CVD) technique, including several steps. The first consisted of fluidizing the metal powder in the coating chamber. For this purpose, vibrations were used, coupled to hydrocarbons-containing gases flowing in the chamber. Next, hydrocarbon decomposition was induced by enhancing the temperature, generating the carbon source to produce graphene. Lastly, graphene was nucleated, growing on the surface of the metal powder.

Fluidized bed CVD (FBCVD) has recently been adopted for coating metal powders [142]. It can form homogeneous coatings due to its capability of suspending each particle in the reactor. Particles are surrounded by the flowing gas containing the reactive gaseous precursor. Liu et al. [48] used $\mathrm{C}_{2} \mathrm{H}_{2}$ as the gaseous precursor of CNTs and Ar as the carrier gas. The decomposition temperature has been set to $550{ }^{\circ} \mathrm{C}$; at this temperature, $\mathrm{C}_{2} \mathrm{H}_{2}$ decomposed, nucleating on Ti-6Al-4V powder surface. With a continuous flux of gases, the CNTs started to grow on metal powders leading to the formation of a homogeneous coating. FBCVD does not impact on powders geometry and guarantees uniform coating and the maintenance of the original spherical geometry of the powders. In the 
paper authors noticed that the degree of sphericity corresponding to the ratio (equivalent surface area diameter)/(equivalent circumscribed circle diameter) varies from 91.6 to 90.2. Such values lead to a good flowability of the particles and consequentially to acceptable processability $[48,63,143-145]$. FBCVD also allows depositing particles characterized by strong vdW interactions, otherwise very difficult to be uniformly deposited [143]. A scheme of FBCVD is shown in Figure 4.
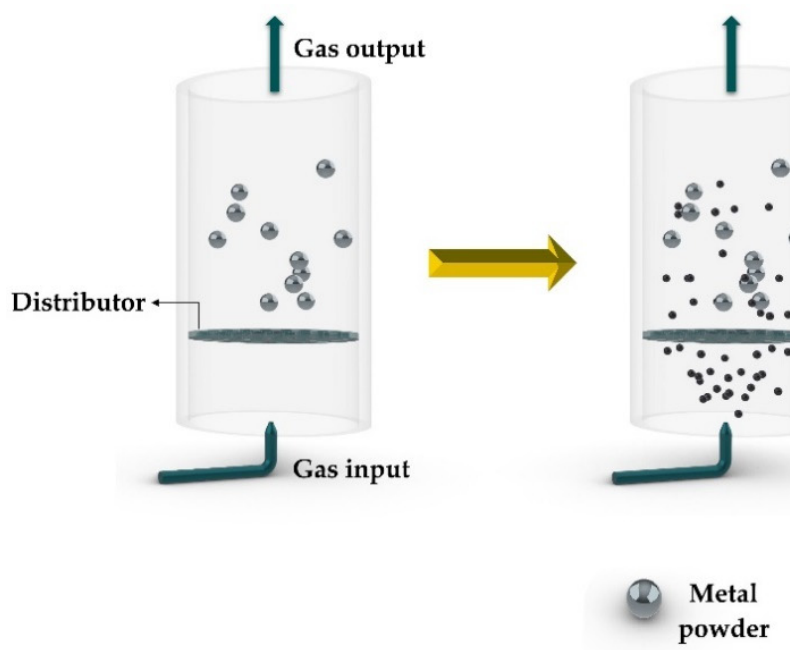

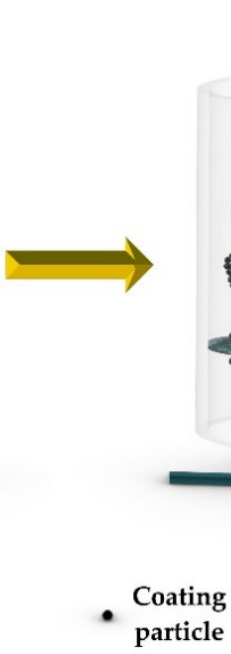

Figure 4. Schematic diagram of FBCVD process for coating powders, the objects in figures are not in scale.

Li et al. [64] underline the importance of adopting a catalyst to synthetize CNTs. For this reason, they evaluated how to introduce catalysts on the surface of the powder before the FBCVD processing. Fe and Ni impurities in Ti-6Al-4V and other alloys have a catalytic effect: a chemical etching was performed to activate these species $[48,64,143]$. However, catalytic impurities cannot be introduced in $\mathrm{Al}$ powders; a $0.1 \mathrm{wt} . \%$ catalyst was therefore inserted through electro-less plating $[64,144]$. A catalyst on the powders' surface leads to a better interfacial bonding strength and an excellent interfacial relationship between the powders and the FBCVD coating.

Pannitz et al. [146] coated steel powders with few-layer graphene (FLG) or silicon carbide ( $\mathrm{SiC}$ ) adopting a top spray configuration of the fluidized bed coating process; in particular, they used the scheme of the process reported in Figure 5. Moreover, Lüddecke et al. [67] applied this method for coating steel and aluminum powders with FLG or SiC or iron oxide black (IOB).

The deposition consists in spraying the solution containing the coating particles on metal powders; then, a drying step is provided. The coatings deposited via this technique are homogeneous $[67,146]$. After the coating step, no significant variation in powders' size is noticeable. As a general result, the laser absorption increases for all the coatings investigated in these studies (few-layer graphene (FLG), silicon carbide ( $\mathrm{SiC}$ ), iron oxide black (IOB)). In particular, FLG resulted in being the most efficient in reducing the metal reflectance; $\mathrm{SiC}$ particles can enhance the powder's flowability, while IOB is not as efficient due to its high water content. 


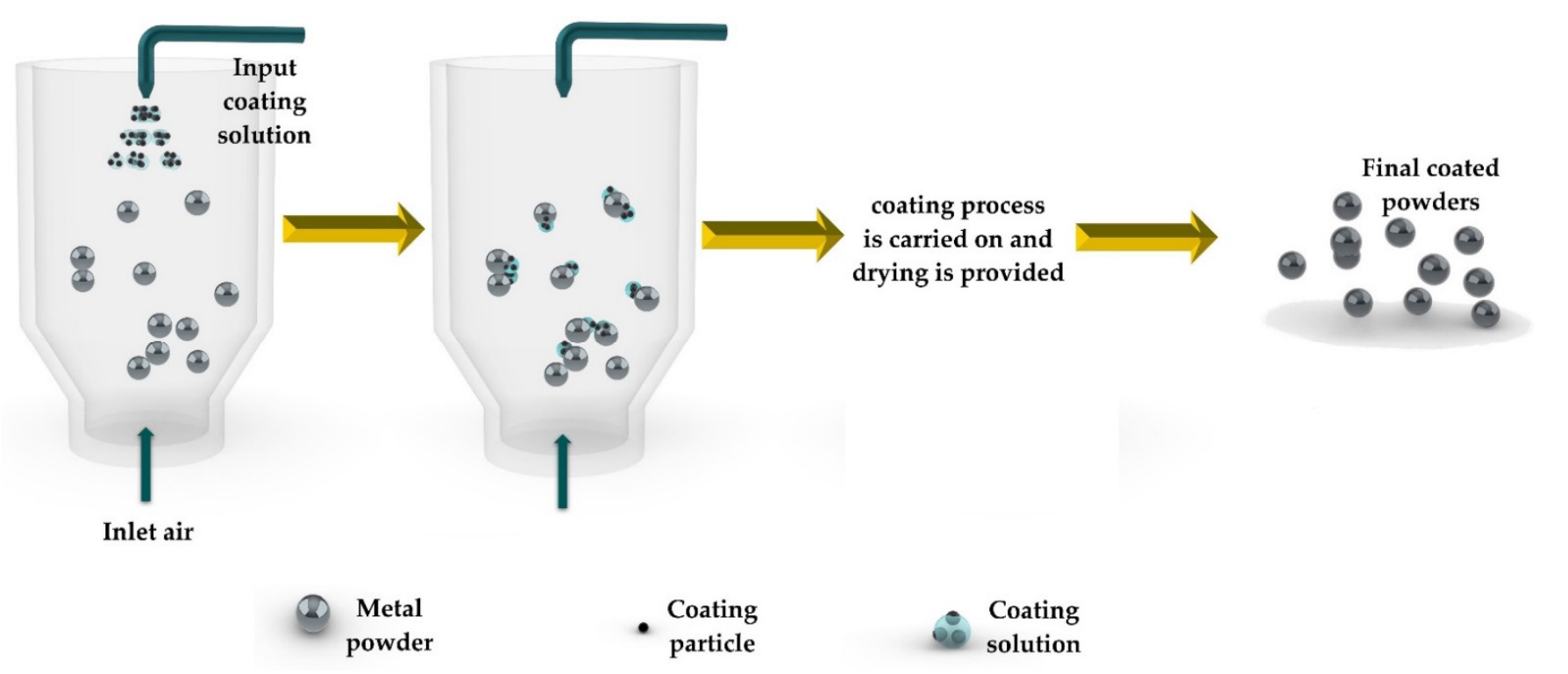

Figure 5. Schematic diagram of fluidized bed process for coating powders, the objects constituting figures are not in scale.

Physical vapor deposition (PVD) techniques have successfully been used to deposit coatings on metal powders, to be further processed through AM, HIP, and press and sinter [20,147-150]. An homogeneous coating of stainless steel on copper powder and coating of copper on stainless steel powder were obtained by Matos et al. [147]. They used a high-frequency vibration system to keep metal powders moving during the deposition coating, adopting a laboratory-made dc magnetron sputtering system; this process was performed in a vacuum chamber. The coating layer is nanocrystalline regardless of the particle shape, and coated powders show a reduction in interparticle friction. Fernandes et al. $[148,150]$ adopted this technique to obtain a homogeneous coating on WC powders, providing the complete coverage of powders' surface and low coating contents ( 1 wt.\%). The coating layer led to an increase in the average powder size from $9.1 \pm 0.5 \mu \mathrm{m}$ to $10.7 \pm 0.3 \mu \mathrm{m} \mathrm{[148]}$. The increase of the average powder size is also related to a high nanoporosity of the coating layer (around 20\%), implying an increase in surface roughness and consequentially in the specific surface area. The coating is permeable to air; however, an increase in coating thickness leads to a decrease in permeability and provides a better oxidation resistance. Simões et al. [149] used PVD for coating powders for HIPping. They noticed an agglomeration of particles during the deposition caused by the non-spherical geometry of the particles, the finer particles, and the broad particle size distribution.

PVD-coated $\mathrm{Cu}$ powders were used by Lassègue et al. [20] and Tiberto et al. [46] for L-PBF processing. Lassègue et al. [20] used CrZr particles to coat $\mathrm{Cu}$ powders; the authors obtained a coating non-homogeneous in thickness (from 32 to $445 \mathrm{~nm}$ ). Despite the dishomogeneities and the poor adhesion of the coating film on the $\mathrm{Cu}$ powders, a considerable increase of optical absorbance is reported, without major impacts on the processability of the coated powder. Tiberto et al. analyzed powders coated with titanium and reported an increase in laser absorbance of titanium coating film, characterized by a thickness of approx. 86-95 $\mathrm{nm}$ [46].

Jadhav et al. $[18,151,152]$ developed a specific coating method for high reflective metals powders in L-PBF manufacturing, consisting of pre-alloying the metal powder with an alloying element that can react with carbon and nitrogen generating nitrides, carbides, or carbonitrides. In addition, the alloying element must have a low or zero miscibility at room temperature with the highly reflective metal. The alloyed metal powder can then be treated in two different ways: (a) Coated using CVD, PVD, or other methods with a coating containing $\mathrm{C}$ or $\mathrm{N}$ and then treated in a furnace; (b) directly heat-treated in nitrogen or carbon or nitrogen-carbon atmosphere. In both cases, the heat treatment temperature is set at $600-850^{\circ} \mathrm{C}$ for at least $1 \mathrm{~h}$. During the treatment, chemical reactions occur between 
the alloy element and $\mathrm{C}$ or $\mathrm{N}$ contained in the coating or the atmosphere, leading to carbides, nitrides, or carbonitrides. Powders after the heat treatment are characterized by the structure shown in Figure 6.

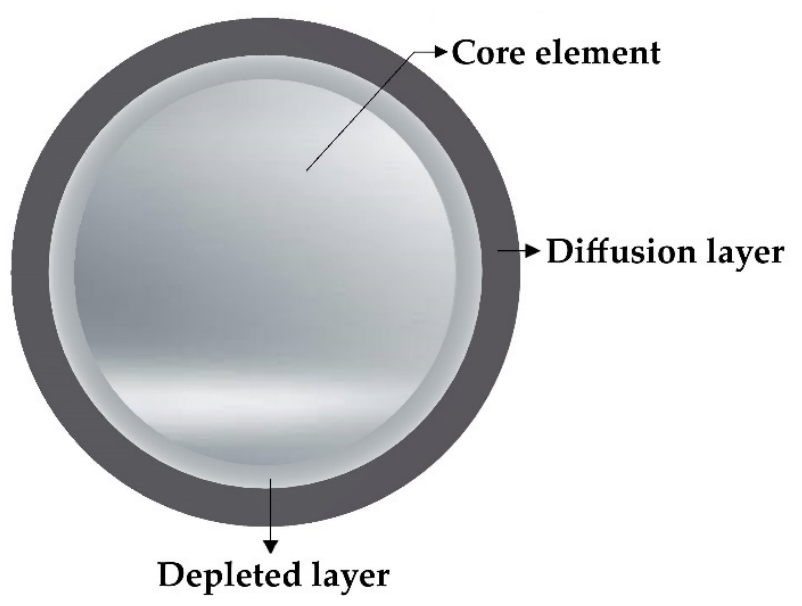

Figure 6. Schematic cross-section of a coated powder, the thickness of the different layers is not in scale.

The powder can be ideally divided into three parts: (1) the surface, corresponding to the diffusion layer having a thickness around $459 \mathrm{~nm}$, composed of carbides, nitrides, or carbonitrides of the alloying element and this last in its metallic form; (2) a depleted layer characterized by the highly reflective metal that has been depleted of the alloying element passed in the diffusion layer; (3) the core, whose composition is that of the pre-alloyed powder. This process leads to a considerable increase in absorbance. Nitrogen is finally released from the powders in the L-PBF processing not to affect the chemical composition of the final part.

Based on the aforementioned, in Table 1 a summarizing scheme is provided.

Table 1. A schematic summary of the coating methods' characteristics.

\begin{tabular}{cccc}
\hline Coating Method & Feasibility of the Process & $\begin{array}{c}\text { Dispersion of the Coating } \\
\text { Particles }\end{array}$ & Cost of the Process \\
\hline HEBM & Easy & Good & Low \\
\hline LEBM & Easy & Good & Low \\
\hline Powders immersion & Complex & Excellent & Depends on the specific adopted \\
method
\end{tabular}

\section{Properties of L-PBF Processed Parts}

AlMangour et al. [104] obtained a relative density of 99.99\% using 316L powders with $5 \% \mathrm{TiB}_{2}$; they also detected increased compressive mechanical yield strength $\left(\sigma_{0.2}=827.5 \pm 17.0 \mathrm{MPa} @ \mathrm{TiB}_{2}=5\right.$ vol. $\% ; \sigma_{0.2}=980.9 \pm 10.9 \mathrm{MPa} @ \mathrm{TiB}_{2}=10$ vol. $\left.\%\right)$ and ductility. Parts produced with coated powders through ball milling and parts deriving from the powders direct mixing were analyzed [27]. As for the hardness, no relevant difference was detected after adding $2.5 \mathrm{vol} . \% \mathrm{TiB}_{2}$ while the parts obtained from ballmilled powders showed a higher hardness when the $\mathrm{TiB}_{2}$ content is $15 \%$. The effect of HIP after L-PBF was also evaluated, which resulted in the elimination of significant cracks and pores. A long HIP cycle however caused a decrease in hardness and wear resistance, due to the transformation of equiaxed grains into nanoparticles agglomeration. Pannitz et al. [146] processed stainless steel 1.4404 grade powders coated with $\mathrm{SiC}$ (4 vol.\%), $\mathrm{SiC}$ ( 1 vol. $\%$ ), and FLG (0.75 vol.\%). Relative densities of $93.9 \%, 99.9 \%$, and $99.9 \%$ respectively 
were obtained. The addition of few-layer graphene (FLG) led to an improvement in laser absorbance and faster heat dissipation into the solidified layer during the printing process. Doñate-Buendia et al. [25] registered an increase of $29 \%$ in compressive strength using a ferritic stainless steel powder PM2000 (74.90 wt.\% Fe, 20.40 wt.\% Cr, 3.94 wt.\% Al, and 0.58 wt. $\%$ Ti, Si, and $\mathrm{Cu}$ traces) nanocoated with $\mathrm{Y}_{2} \mathrm{O}_{3}$. Wilms et al. [131] obtained a final porosity of $0.5 \%$ processing a ferritic stainless steel powder (Nanoval-21.03 wt.\% $\mathrm{Cr}$, 4.67 wt. $\%$ Al and 0.47 wt. $\% \mathrm{Ti}$ ) homogenously decorated with nano-scaled $\mathrm{Y}_{2} \mathrm{O}_{3}$ powder particles. No cracks and no increment in hardness have been detected, while an increase in compressive strength was reached. AlMangour et al. [29] detected an improved density by introducing finer coating particles onto 316L; they also noticed an increase in hardness when increasing the $\mathrm{TiC}$ content.

Attar et al. [26] reached a relative density of $99.50 \%$ by coating titanium powders with $\mathrm{TiB}_{2}$; such coating increases hardness due to the formation of titanium monoboride from the reaction between $\mathrm{TiB}_{2}$ and the Ti matrix. Kun et al. [110] used TiC nanoparticles, resulting in an increased tensile strength $(914 \mathrm{MPa})$ with a ductility comparable to the uncoated Ti powders. Zhou et al. [62] determined that CNTs react with the Ti matrix generating $\mathrm{TiC}$ and leading to an increase of hardness compared to $\mathrm{Ti}$ and the titanium matrix composites produced by traditional processes; the final microstructure is finer with a uniform distribution of $\mathrm{TiC}$ particles. Liu et al. [48] produced Ti-6Al-4V samples starting from powders coated with CNTs; this material is characterized by a higher ultimate tensile strength (1255 MPa instead of $1078 \mathrm{MPa})$, yield strength (1162 MPa instead of $964 \mathrm{MPa})$, and lower elongation (3.2\% from $4.2 \%$ ) compared to the material produced from uncoated Ti-6Al-4V powders.

Geng et al. [144] noticed that CNTs react with Al during printing; this led to the formation of $\mathrm{Al}_{4} \mathrm{C}_{3}$ distributed inside the grains and has a strengthening effect. Based on the results presented by the authors, compared to uncoated aluminum powders, both the ultimate strength and the yield strength increased, the first from $82 \mathrm{MPa}$ to $129 \mathrm{MPa}$ while the second varied from 66 to $99 \mathrm{MPa}$. No difference was detected in the tensile elongation. Geng et al. [125] evaluated the variation of mechanical properties at increased fractions of $\mathrm{Ni}$ deposited on the surface of pure Al powders. The authors found that the optimal fraction of $\mathrm{Ni}$ is $5 \mathrm{wt} \%$, since it increases the ultimate tensile strength from $124 \pm 2.5 \mathrm{MPa}$ to $182 \pm 0.5 \mathrm{MPa}$ and the yield strength from $95 \pm 2 \mathrm{MPa}$ to $146 \pm 1 \mathrm{MPa}$ without reducing its elongation. A chemical reaction occurred between the coating (Ni) and the matrix, generating the second-phase $\mathrm{Al}_{3} \mathrm{Ni}$. In another study, Geng et al. [126] observed that also Co coating reacts with $\mathrm{Al}$ matrix leading to the formation of $\mathrm{Al}_{9} \mathrm{Co}_{2}$; this second phase and the $\mathrm{Al}$ matrix have a coherent interfacial relationship. The authors also measured the surface roughness of the printed objects, which was lower than the pure Al parts: surface roughness decreased as Co content was raised (the maximum content of Co introduced is $1.1 \mathrm{wt} . \%)$. Zhou et al. [128] observed the precipitation of $\mathrm{Al}_{4} \mathrm{C}_{3}$ nanorods when printing aluminum powders coated with graphene oxide (GO). Such precipitates are monocrystalline and increase the mechanical properties owing to their intimate contact with the matrix. Jue et al. [22] obtained a relative density of $97.30 \%$ and a hardness equal to $175 \mathrm{HV} 0.1$ by coating $\mathrm{Al}$ powders with $\mathrm{Al}_{2} \mathrm{O}_{3}$. Gu et al. [107] reached a hardness of 188.3 HV0.1 and tensile strength of $486 \mathrm{MPa}$ while the elongation remained constant after coating Al powders with TiC. Mair et al. [28], in their study about $2024 \mathrm{Al}$ alloy decorated with $\mathrm{CaB}_{6}$, were able to print parts characterized by an equiaxed microstructure, with a relative density of $99.5 \%$, hardness equal to $132 \pm 4 \mathrm{HV} 5$, a tensile strength of $391 \pm 22 \mathrm{MPa}$, a yield strength of $348 \pm 16 \mathrm{MPa}$, and elongation equal to $12.6 \pm 0.6 \%$. Dong et al. [63] noticed that GO sheets applied onto an AlSi10Mg powder partially reacts with the matrix leading to the formation of $\mathrm{Al}_{4} \mathrm{C}_{3}$. They also found two different types of porosity, the smaller ones represented by gas porosities, while the bigger and irregular ones to be attributed to the fact that the GO sheets retain their shape during melting. Nevertheless, an increase in hardness has been detected. 
By processing a $\mathrm{CuCr}$ powder with surface modified with N, Jadhav et al. [18] obtained samples characterized by a thermal and electrical conductivity lower than the un-modified material, but with a higher elongation at break and yield and tensile strengths. Solution annealing and age hardening caused an improvement of all the aforementioned properties, a part from elongation at break. In a previous study, on the evaluation of the addition of $0.1 \mathrm{wt} . \%$ carbon nanoparticles on gas atomized $\mathrm{Cu}$ powder with purity of 99.7 , Jadhav et al. [19] produced parts with a relative density of $98 \%$ and a tensile strength of $125 \pm 11 \mathrm{MPa}$. Using a CrZr-coated Cu powder, Lassègue et al. [20] obtained samples with a relative density of $94.3 \%$ instead of $87.3 \%$ for the uncoated powders. Jadhav et al. [17] evidenced the importance of having sulfur-free copper powders as starting material in order to reduce the occurrence of defects such as porosity and solidification cracks. By using sulfur-free powders, authors obtained a tensile strength of $256 \pm 14 \mathrm{MPa}$, a yield strength of $203 \pm 4 \mathrm{MPa}$, and hardness of $90 \pm 3 \mathrm{HV0.3}$, with electrical and thermal conductivity respectively of $80 \pm 1 \%$ international annealed copper standard (IACS) and $334 \pm 4(\mathrm{~W} /(\mathrm{m} \cdot \mathrm{K}))$. Lindström et al. [21] underlined the importance of incrementing the laser absorbance to reach higher final densities in the printed parts.

Smith et al. [56] performed a HIP cycle on the AM-produced parts, highlighting that ceramic nanoparticles have a pinning effect leading to the suppression of grain growth and recrystallization.

Tables 2-5 provide a summary of the L-PBF process parameters applied on different coated powders, including the relative density and mechanical properties measured on printed parts. 
Table 2. A summary table reporting L-PBF process parameters, relative density and mechanical properties of printed parts using Fe-based alloys.

\begin{tabular}{|c|c|c|c|c|c|c|c|c|c|}
\hline Metal Powder & Coating & $\begin{array}{l}\text { Coating } \\
\text { Technique }\end{array}$ & Ref. & $\begin{array}{l}\text { Laser Power } \\
\text { (W) }\end{array}$ & $\begin{array}{c}\text { Scanning } \\
\text { Speed }(\mathrm{mm} / \mathrm{s})\end{array}$ & $\begin{array}{c}\text { Hatching } \\
\text { Distance }(\mu \mathrm{m})\end{array}$ & $\begin{array}{c}\text { Layer } \\
\text { Thickness }(\mu \mathrm{m})\end{array}$ & Relative Density & Mechanical Properties \\
\hline \multirow{10}{*}{ steels } & $\mathrm{TiB}_{2}$ & Ball milling & [104] & 100 & 83.33 & - & 50 & $99.99 \%$ & $\sigma_{0.2}{ }^{2}=980.9 \pm 10.9 \mathrm{MPa}$ \\
\hline & $\mathrm{TiC}$ & Ball milling & [106] & 100 & - & 120 & - & $\begin{array}{c}98.22 \% @ \eta^{3}=300 \\
\mathrm{~J} / \mathrm{mm}^{3}\end{array}$ & $\begin{array}{c}\text { Max compressive yield } \\
\text { strength @ } \eta^{3}=67 \mathrm{~J} / \mathrm{mm}^{3}\end{array}$ \\
\hline & $\mathrm{Y}_{2} \mathrm{O}_{3}$ & Ball milling & [105] & 250 & 1200 & - & 40 & $\begin{array}{c}99.6 \% @ 0.3 \text { wt. } \% \\
\mathrm{Y}_{2} \mathrm{O}_{3}\end{array}$ & 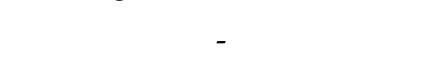 \\
\hline & $\mathrm{TiB}_{2}$ & Ball milling & [27] & 100 & 83.33 & 120 & 50 & $91.5 \%$ & $\begin{array}{c}\text { Hardness } \sim 600 \mathrm{HV} \\
\mathrm{COF}^{4}=0.161 @ 15 \text { vol. } \% \mathrm{TiB}_{2} \\
\text { Wear resistance }=1.93 \times 10^{-7} \\
\mathrm{~mm}^{3} /(\mathrm{N} \cdot \mathrm{m}) @ 15 \text { vol. } \% \mathrm{TiB}_{2}\end{array}$ \\
\hline & $\mathrm{TiC}$ & Ball milling & [29] & 100 & 250 & 50 & 50 & $\begin{array}{c}\sim 96 \% @ 2.5 \text { vol. } \% \\
\text { nm-TiC }\end{array}$ & $\begin{array}{c}\text { Hardness = } 403 \text { HV0.2@ } 15 \\
\text { vol. } \% \text { nm-TiC }\end{array}$ \\
\hline & $\mathrm{SiC}$ & Ball milling & [119] & 100 & 330 & 40 & 50 & - $299.9 \% @ 1$ vol.\% & $\mathrm{TS}^{6}=753 \pm 49 \mathrm{MPa}$ \\
\hline & $\mathrm{FLG} / \mathrm{SiC}$ & Fluidized bed & [146] & 130 & 700 & 80 & 30 & $\begin{array}{l}\mathrm{SiC} \text { and } 0.75 \text { vol. } \% \\
\text { FLG }\end{array}$ & - \\
\hline & & & & & & & & & $\begin{array}{c}\text { Hardness }=249 \pm 7 \mathrm{HV} 0.1 \\
\sigma_{\mathrm{c}, \mathrm{p} 0.2}{ }^{5}=538 \pm 17 @ \mathrm{~T}_{\mathrm{amb}} \\
\sigma_{\mathrm{c}, \mathrm{p} 0.2}{ }^{5}=430 \pm 11 @ 600^{\circ} \mathrm{C}\end{array}$ \\
\hline & $\mathrm{Y}_{2} \mathrm{O}_{3}$ & Solution ${ }^{1}$ & [25] & 160 & 800 & 60 & 30 & - & $\begin{array}{c}\sigma_{\mathrm{c}, \mathrm{p} 5}{ }^{5}=720 \pm 15 @ \mathrm{~T}_{\mathrm{amb}} ; \sigma_{\mathrm{c}, \mathrm{p} 5} \\
5=620 \pm 30 @ 600{ }^{\circ} \mathrm{C} \\
\sigma_{\mathrm{c}, \mathrm{p} 15}{ }^{5}=900 \pm 30 @ \mathrm{~T}_{\mathrm{amb}} ; \\
\sigma_{\mathrm{c}, \mathrm{p} 15}{ }^{5}=720 \pm 30 @ 600^{\circ} \mathrm{C}\end{array}$ \\
\hline & $\mathrm{Y}_{2} \mathrm{O}_{3}$ & Solution ${ }^{1}$ & [131] & 160 & 800 & - & 30 & $99.2 \%$ & - \\
\hline
\end{tabular}

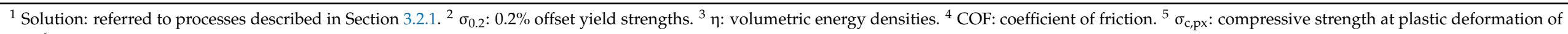
$\mathrm{x} \% .{ }^{6}$ TS: tensile strength. 
Table 3. A summary table reporting L-PBF process parameters, relative density and mechanical properties of printed parts using Ti-based alloys.

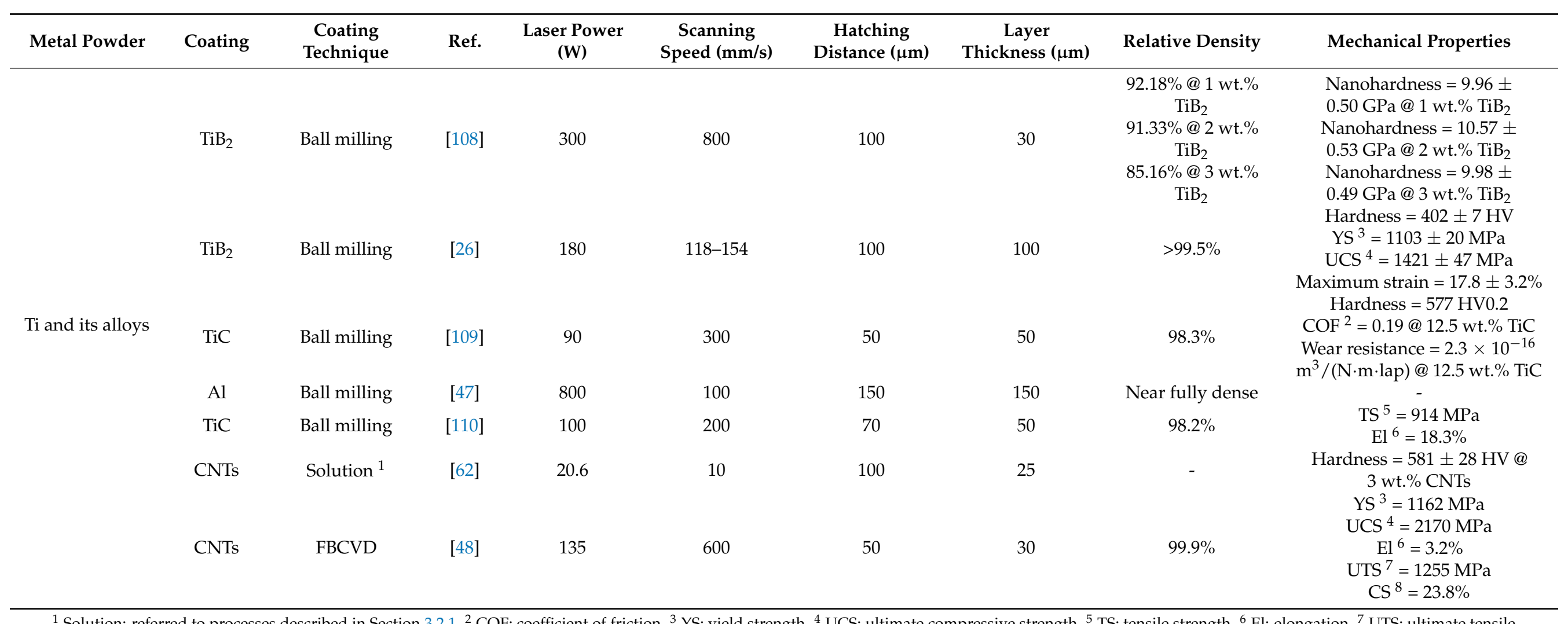

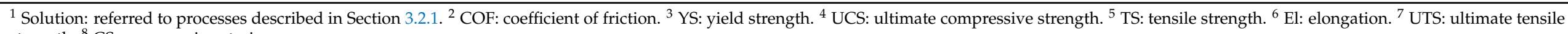
strength. ${ }^{8}$ CS: compressive strain. 
Table 4. A summary table reporting L-PBF process parameters, relative density and mechanical properties of printed parts using Al-based alloys.

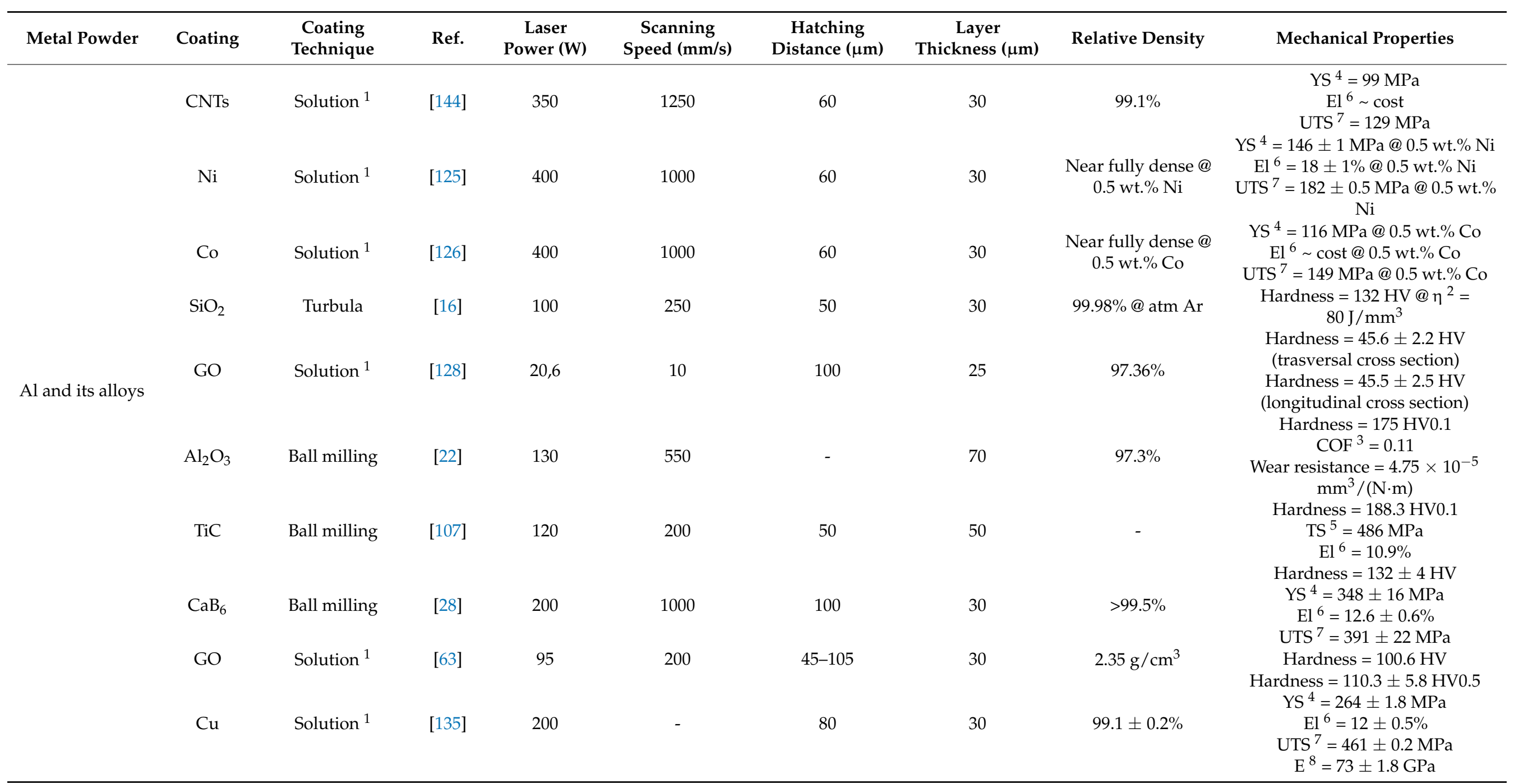

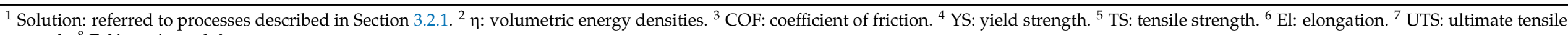
strength. ${ }^{8} \mathrm{E}$ : Young's modulus. 
Table 5. A summary table reporting L-PBF process parameters, relative density and mechanical properties of printed parts using Cu-based alloys.

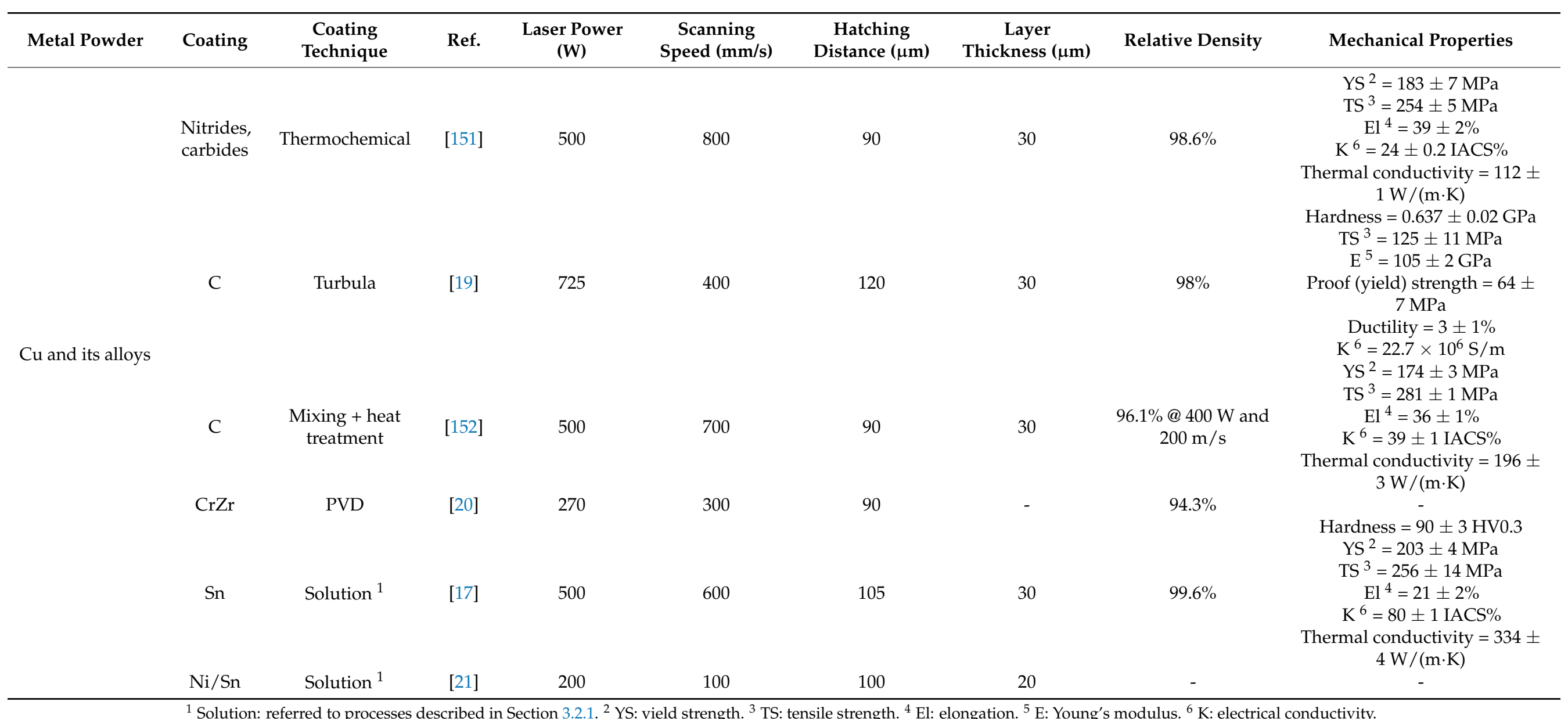

${ }^{1}$ Solution: referred to processes described in Section 3.2.1. ${ }^{2}$ YS: yield strength. ${ }^{3}$ TS: tensile strength. ${ }^{4}$ El: elongation. ${ }^{5}$ E: Young's modulus. ${ }^{6}$ K: electrical conductivity. 


\section{Conclusions}

Powders coating processes are of increasing interest; the possible applications of coated metal powders are wide and involve many aspects such as processability, mechanical, and physical properties. Different ways of coating are possible. The so-called mechanical coating techniques were among the first adopted. However, when high energy is involved, a severe plastic deformation occurs, modifying powders' shape and impairing the powders' flowability. On the other hand, coating processes involving chemical solutions do not affect the geometry and size distribution of the powders, usually resulting in homogeneous and continuous coatings. These processes are characterized by different difficulties such as the limited quantity of powder that can be treated together, the costs and the complexity of the process itself; for these reasons it is mandatory to evaluate new techniques not currently in the market in order to obtain constant and homogenous coating which can provide higher processability.

Coated powders can improve L-PBF processability, in terms of higher flowability and absorbance, especially for those metals characterized by a high laser reflectivity. The surface modification of powder can pursue a higher laser absorbance. Two main factors are involved: the surface roughness, which is usually increased by coatings, and the choice of coating material with a high absorbance coefficient. Several parameters influence flowability as well. A higher surface roughness can negatively affect it, whereas ceramic nanoparticles can increase it, due to the intrinsic low van der Waals forces.

Mechanical properties of the final parts can also be improved by processing suitably coated powders. Hardness can increase by using ceramic coating particles or by the grain refining effect. Using metal powders homogeneously coated by nanoparticles may result in an improvement of tensile strength and hardness without sacrificing ductility.

Author Contributions: Conceptualization, F.S.G., M.C. and M.A.G.; validation, F.S.G., M.C. and M.A.G.; formal analysis, F.S.G.; investigation, M.C., F.S.G.; resources, M.A.G., J.B.; data curation, M.C., F.S.G.; writing —original draft preparation, M.C., F.S.G.; writing—review and editing, M.A.G., F.S.G., R.B.; supervision, T.K., M.A.G., R.B., J.B. All authors have read and agreed to the published version of the manuscript.

Funding: This research was funded by VEGA grant number 1/0599/18.

Institutional Review Board Statement: Not applicable.

Informed Consent Statement: Not applicable.

Data Availability Statement: Not applicable.

Conflicts of Interest: The authors declare no conflict of interest.

\section{References}

1. Fujiki, A. Present state and future prospects of powder metallurgy parts for automotive applications. Mater. Chem. Phys. 2001, 67, 298-306. [CrossRef]

2. Ramakrishnan, P. Automotive applications of powder metallurgy. In Advances in Powder Metallurgy; Woodhead Publishing Limited: Sawston, UK, 2013; pp. 493-519.

3. Vicenzi, B.; Boz, K.; Aboussouan, L. Powder metallurgy in aerospace-Fundamentals of pm processes and examples of applications. Acta Metall. Slovaca 2020, 26, 144-160. [CrossRef]

4. Kondo, H.; Hegedus, M. Current trends and challenges in the global aviation industry. Acta Metall. Slovaca 2020, 26, 141-143. [CrossRef]

5. Vasanthakumar, P.; Sekar, K.; Venkatesh, K. Recent developments in powder metallurgy based aluminium alloy composite for aerospace applications. Mater. Today Proc. 2019, 18, 5400-5409. [CrossRef]

6. $\quad$ Fang, Z.Z.; Paramore, J.D.; Sun, P.; Chandran, K.S.R.; Zhang, Y.; Xia, Y.; Cao, F.; Koopman, M.; Free, M. Powder metallurgy of titanium-Past, present, and future. Int. Mater. Rev. 2018, 63, 407-459. [CrossRef]

7. Javanbakht, M.; Salahinejad, E.; Hadianfard, M.J. The effect of sintering temperature on the structure and mechanical properties of medical-grade powder metallurgy stainless steels. Powder Technol. 2016, 289, 37-43. [CrossRef]

8. Dias, M.; Mozetic, H.; Barboza, J.; Martins, R.; Pelegrini, L.; Schaeffer, L. Influence of resin type and content on electrical and magnetic properties of soft magnetic composites (SMCs). Powder Technol. 2013, 237, 213-220. [CrossRef] 
9. Slusarek, B.; Kapelski, D.; Antal, L.; Zalas, P.; Gwozdziewicz, M. Synchronous Motor with Hybrid Permanent Magnets on the Rotor. Sensors 2014, 14, 12425-12436. [CrossRef] [PubMed]

10. Mustafa, L.; Anjum, S.; Waseem, S.; Khurshid, H.; Javed, S. Structural, Electrical, Optical and Magnetic Properties of Zn $n_{0.9} \mathrm{Co}_{0.1} \mathrm{O}$, $\mathrm{Zn}_{0.9} \mathrm{Ni}_{0.1} \mathrm{O}, \mathrm{Zn}_{0.9} \mathrm{Co}_{0.06} \mathrm{Ni}_{0.04} \mathrm{O}$; Elsevier Ltd.: Amsterdam, The Netherlands, 2015; Volume 2.

11. Bidulský, R.; Grande, M.A.; Ferraris, L.; Ferraris, P.; Bidulská, J. The Effects of Chemical Composition on Soft Magnetic Materials Behaviour. Acta Phys. Pol. A 2010, 118, 802-803. [CrossRef]

12. Panda, A.; Dobránsky, J.; Jančík, M.; Pandová, I.; Kačalová, M. Advantages and effectiveness of the powder metallurgy in manufacturing technologies. Metalurgija 2018, 57, 353-356.

13. Klar, E.; Samal, P.K. Introduction. In Powder Metallurgy Stainless Steels: Processing, Microstructures, and Properties; ASM International: Novelty, OH, USA, 2007; p. 1. ISBN 978-0-87170-848-9.

14. Upadhyaya, G.S. Introduction. In Powder Metallurgy Technology; Cambridge International Science Publishing: Cambridge, UK, 1996; pp. 1-3.

15. Hentschel, O.; Siegel, L.; Scheitler, C.; Huber, F.; Junker, D.; Gorunow, A.; Schmidt, M. Processing of AISI H11 Tool Steel Powder Modified with Carbon Black Nanoparticles for the Additive Manufacturing of Forging Tools with Tailored Mechanical Properties by Means of Laser Metal Deposition (LMD). Metals 2018, 8, 659. [CrossRef]

16. Karg, M.C.H.; Munk, A.; Ahuja, B.; Backer, M.V.; Schmitt, J.P.; Stengel, C.; Kuryntsev, S.V.; Schmidt, M. Expanding particle size distribution and morphology of aluminium-silicon powders for Laser Beam Melting by dry coating with silica nanoparticles. $J$. Mater. Process. Technol. 2019, 264, 155-171. [CrossRef]

17. Jadhav, S.D.; Fu, D.; Deprez, M.; Ramharter, K.; Willems, D.; Van Hooreweder, B.; Vanmeensel, K. Highly conductive and strong CuSn0.3 alloy processed via laser powder bed fusion starting from a tin-coated copper powder. Addit. Manuf. 2020, 36, 101607. [CrossRef]

18. Jadhav, S.D.; Dhekne, P.P.; Dadbakhsh, S.; Kruth, J.-P.; Van Humbeeck, J.; Vanmeensel, K. Surface Modified Copper Alloy Powder for Reliable Laser-based Additive Manufacturing. Addit. Manuf. 2020, 35, 101418. [CrossRef]

19. Jadhav, S.D.; Dadbakhsh, S.; Vleugels, J.; Hofkens, J.; Van Puyvelde, P.; Yang, S.; Kruth, J.-P.; Van Humbeeck, J.; Vanmeensel, K. Influence of Carbon Nanoparticle Addition (and Impurities) on Selective Laser Melting of Pure Copper. Materials 2019, 12, 2469. [CrossRef] [PubMed]

20. Lassègue, P.; Salvan, C.; De Vito, E.; Soulas, R.; Herbin, M.; Hemberg, A.; Godfroid, T.; Baffie, T.; Roux, G. Laser powder bed fusion (L-PBF) of $\mathrm{Cu}$ and $\mathrm{CuCrZr}$ parts: Influence of an absorptive physical vapor deposition (PVD) coating on the printing process. Addit. Manuf. 2021, 39, 101888. [CrossRef]

21. Lindström, V.; Liashenko, O.; Zweiacker, K.; Derevianko, S.; Morozovych, V.; Lyashenko, Y.; Leinenbach, C. Laser Powder Bed Fusion of Metal Coated Copper Powders. Materials 2020, 13, 3493. [CrossRef]

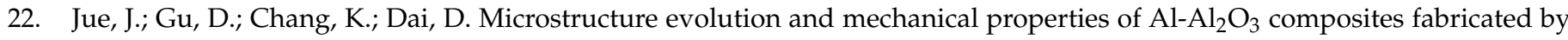
selective laser melting. Powder Technol. 2017, 310, 80-91. [CrossRef]

23. Han, Q.; Setchi, R.; Evans, S. Synthesis and characterisation of advanced ball-milled $\mathrm{Al}_{-} \mathrm{Al}_{2} \mathrm{O}_{3}$ nanocomposites for selective laser melting. Powder Technol. 2016, 297, 183-192. [CrossRef]

24. Güler, O.; Varol, T.; Alver, Ü.; Kaya, G.; Yıldız, F. Microstructure and wear characterization of $\mathrm{Al}_{2} \mathrm{O}_{3}$ reinforced silver coated copper matrix composites by electroless plating and hot pressing methods. Mater. Today Commun. 2021, 27, 102205. [CrossRef]

25. Doñate-Buendia, C.; Kürnsteiner, P.; Stern, F.; Wilms, M.; Streubel, R.; Kusoglu, I.; Tenkamp, J.; Bruder, E.; Pirch, N.; Barcikowski, S.; et al. Microstructure formation and mechanical properties of ODS steels built by laser additive manufacturing of nanoparticle coated iron-chromium powders. Acta Mater. 2021, 206, 116566. [CrossRef]

26. Attar, H.; Bönisch, M.; Calin, M.; Zhang, L.-C.; Scudino, S.; Eckert, J. Selective laser melting of in situ titanium-titanium boride composites: Processing, microstructure and mechanical properties. Acta Mater. 2014, 76, 13-22. [CrossRef]

27. AlMangour, B.; Grzesiak, D.; Yang, J.-M. Selective laser melting of TiB2/316L stainless steel composites: The roles of powder preparation and hot isostatic pressing post-treatment. Powder Technol. 2017, 309, 37-48. [CrossRef]

28. Mair, P.; Goettgens, V.S.; Rainer, T.; Weinberger, N.; Letofsky-Papst, I.; Mitsche, S.; Leichtfried, G. Laser powder bed fusion of nano-CaB6 decorated 2024 aluminum alloy. J. Alloys Compd. 2021, 863, 158714. [CrossRef]

29. AlMangour, B.; Grzesiak, D.; Yang, J.-M. Selective laser melting of TiC reinforced 316L stainless steel matrix nanocomposites: Influence of starting TiC particle size and volume content. Mater. Des. 2016, 104, 141-151. [CrossRef]

30. Vafadar, A.; Guzzomi, F.; Rassau, A.; Hayward, K. Advances in Metal Additive Manufacturing: A Review of Common Processes, Industrial Applications, and Current Challenges. Appl. Sci. 2021, 11, 1213. [CrossRef]

31. DIN EN ISO/ASTM 52900 Additive manufacturing-General principles-Terminology (ISO/ASTM DIS 52900:2018); German and English version prEN ISO/ASTM 52900. Available online: https:/ / www.din.de/en/getting-involved/standards-committees/ nwt/drafts/wdc-beuth:din21:288079286 (accessed on 11 September 2021).

32. Gebhardt, A. Additive Fertigungsverfahren. In Additive Fertigungsverfahren; Carl Hanser Verlag GmbH \& Co. KG: München, Germany, 2016; pp. I-XXIV. ISBN 978-3-446-44401-0.

33. Yadroitsev, I.; Thivillon, L.; Bertrand, P.; Smurov, I. Strategy of manufacturing components with designed internal structure by selective laser melting of metallic powder. Appl. Surf. Sci. 2007, 254, 980-983. [CrossRef]

34. Yadroitsev, I.; Shishkovsky, I.; Bertrand, P.; Smurov, I. Manufacturing of fine-structured 3D porous filter elements by selective laser melting. Appl. Surf. Sci. 2009, 255, 5523-5527. [CrossRef] 
35. Rombouts, M.; Kruth, J.; Froyen, L.; Mercelis, P. Fundamentals of Selective Laser Melting of alloyed steel powders. CIRP Ann. 2006, 55, 187-192. [CrossRef]

36. DebRoy, T.; Wei, H.L.; Zuback, J.S.; Mukherjee, T.; Elmer, J.W.; Milewski, J.O.; Beese, A.M.; Wilson-Heid, A.; De, A.; Zhang, W. Additive manufacturing of metallic components-Process, structure and properties. Prog. Mater. Sci. 2018, 92, 112-224. [CrossRef]

37. Minetola, P.; Iuliano, L.; Bassoli, E.; Gatto, A. Impact of additive manufacturing on engineering education-evidence from Italy. Rapid Prototyp. J. 2015, 21, 535-555. [CrossRef]

38. Calignano, F.; Manfredi, D.; Ambrosio, E.P.; Biamino, S.; Lombardi, M.; Atzeni, E.; Salmi, A.; Minetola, P.; Iuliano, L.; Fino, P. Overview on Additive Manufacturing Technologies. Proc. IEEE 2017, 105, 593-612. [CrossRef]

39. Thijs, L.; Verhaeghe, F.; Craeghs, T.; Van Humbeeck, J.; Kruth, J.-P. A study of the microstructural evolution during selective laser melting of Ti-6Al-4V. Acta Mater. 2010, 58, 3303-3312. [CrossRef]

40. Gokuldoss, P.K.; Kolla, S.; Eckert, J. Additive Manufacturing Processes: Selective Laser Melting, Electron Beam Melting and Binder Jetting-Selection Guidelines. Materials 2017, 10, 672. [CrossRef]

41. Huang, J.; Yan, X.; Chang, C.; Xie, Y.; Ma, W.; Huang, R.; Zhao, R.; Li, S.; Liu, M.; Liao, H. Pure copper components fabricated by cold spray (CS) and selective laser melting (SLM) technology. Surf. Coat. Technol. 2020, 395, 125936. [CrossRef]

42. Jiang, Q.; Zhang, P.; Yu, Z.; Shi, H.; Wu, D.; Yan, H.; Ye, X.; Lu, Q.; Tian, Y. A Review on Additive Manufacturing of Pure Copper. Coatings 2021, 11, 740. [CrossRef]

43. Prasad, H.S.; Brueckner, F.; Volpp, J.; Kaplan, A.F.H. Laser metal deposition of copper on diverse metals using green laser sources. Int. J. Adv. Manuf. Technol. 2020, 107, 1559-1568. [CrossRef]

44. Lingqin, X.; Guang, C.; Luyu, Z.; Pan, L. Explore the feasibility of fabricating pure copper parts with low-laser energy by selective laser melting. Mater. Res. Express 2020, 7, 106509. [CrossRef]

45. Yang, K.V.; Rometsch, P.; Davies, C.; Huang, A.; Wu, X. Effect of heat treatment on the microstructure and anisotropy in mechanical properties of A357 alloy produced by selective laser melting. Mater. Des. 2018, 154, 275-290. [CrossRef]

46. Tiberto, D.; Klotz, U.E.; Held, F. Processability of $\mathrm{Cu}$ and Cu-Alloys with Laser Beam Melting: Influence of Powder Coating and Alloying Elements. Available online: https:/ / www.fem-online.de/sites/default/files/pdf/Workshop\%208.05.\%20-\%20fem\%20 presentation.pdf (accessed on 14 September 2021).

47. Gu, D.; Wang, Z.; Shen, Y.; Li, Q.; Li, Y. In-situ TiC particle reinforced Ti-Al matrix composites: Powder preparation by mechanical alloying and Selective Laser Melting behavior. Appl. Surf. Sci. 2009, 255, 9230-9240. [CrossRef]

48. Liu, Y.; Li, S.; Misra, R.; Geng, K.; Yang, Y. Planting carbon nanotubes within Ti-6Al-4V to make high-quality composite powders for 3D printing high-performance Ti-6Al-4V matrix composites. Scr. Mater. 2020, 183, 6-11. [CrossRef]

49. Montiel, H.; Xu, B.; Li, J. Selective Laser Melting of Mechanically Alloyed Metastable $\mathrm{Al}_{5} \mathrm{Fe}_{2}$ Powders. J. Manuf. Sci. Eng. 2019, 141, 071008-18. [CrossRef]

50. Kruth, J.-P.; Levy, G.; Klocke, F.; Childs, T. Consolidation phenomena in laser and powder-bed based layered manufacturing. CIRP Ann. 2007, 56, 730-759. [CrossRef]

51. Taruttis, A.; Hardes, C.; Röttger, A.; Uhlenwinkel, V.; Chehreh, A.B.; Theisen, W.; Walther, F.; Zoch, H.W. Laser additive manufacturing of hot work tool steel by means of a starting powder containing partly spherical pure elements and ferroalloys. Procedia CIRP 2020, 94, 46-51. [CrossRef]

52. Abdelwahed, M.; Casati, R.; Bengtsson, S.; Larsson, A.; Riccio, M.; Vedani, M. Effects of Powder Atomisation on Microstructural and Mechanical Behaviour of L-PBF Processed Steels. Metals 2020, 10, 1474. [CrossRef]

53. Cordova, L.; Bor, T.; de Smit, M.; Campos, M.; Tinga, T. Measuring the spreadability of pre-treated and moisturized powders for laser powder bed fusion. Addit. Manuf. 2020, 32, 101082. [CrossRef]

54. Bassini, E.; Marchese, G.; Cattano, G.; Lombardi, M.; Biamino, S.; Ugues, D.; Vallillo, G.; Picqué, B. Influence of solutioning on microstructure and hardness of hot isostatically pressed Astroloy. J. Alloys Compd. 2017, 723, 1082-1090. [CrossRef]

55. Tammas-Williams, S.; Withers, P.J.; Todd, I.; Prangnell, P.B. The Effectiveness of Hot Isostatic Pressing for Closing Porosity in Titanium Parts Manufactured by Selective Electron Beam Melting. Met. Mater. Trans. A 2016, 47, 1939-1946. [CrossRef]

56. Smith, T.M.; Thompson, A.C.; Gabb, T.P.; Bowman, C.L.; Kantzos, C.A. Efficient production of a high-performance dispersion strengthened, multi-principal element alloy. Sci. Rep. 2020, 10, 9663. [CrossRef]

57. King, S.; Rickinson, B.A.; Fletcher, A.J.; Atkinson, H.V. Removal of voids in 70/30 cupronickel castings by hot isostatic pressing. In Hot Isostatic Pressing '93; Elsevier: Amsterdam, The Netherlands, 1994; pp. 145-155.

58. Weddeling, A.; Theisen, W. Energy and time saving processing: A combination of hot isostatic pressing and heat treatment. Met. Powder Rep. 2017, 72, 345-348. [CrossRef]

59. Ekbom, R. Hot isostatic pressing/powder metallurgy in gas and steam turbines. Mater. Des. 1990, 11, 37-42. [CrossRef]

60. Du Plessis, A.; Rossouw, P. Investigation of Porosity Changes in Cast Ti6Al4V Rods After Hot Isostatic Pressing. J. Mater. Eng. Perform. 2015, 24, 3137-3141. [CrossRef]

61. Staley, J.T.; Tiryakioğlu, M.; Campbell, J. The effect of hot isostatic pressing (HIP) on the fatigue life of A206-T71 aluminum castings. Mater. Sci. Eng. A 2007, 465, 136-145. [CrossRef]

62. Zhou, W.; Kamata, K.; Dong, M.; Nomura, N. Laser powder bed fusion additive manufacturing, microstructure evolution, and mechanical performance of carbon nanotube-decorated titanium alloy powders. Powder Technol. 2021, 382, 274-283. [CrossRef] 
63. Dong, M.; Zhou, W.; Kamata, K.; Nomura, N. Microstructure and mechanical property of graphene oxide/AlSi10Mg composites fabricated by laser additive manufacturing. Mater. Charact. 2020, 170, 110678. [CrossRef]

64. Li, S.F.; Geng, K.; Misra, R.D.K.; Cui, J.Y.; Ye, D.; Liu, Y.; Yang, Y.F. Commercial Scale Uniform Powder Coating for Metal Additive Manufacturing. JOM 2020, 72, 4639-4647. [CrossRef]

65. Jadhav, S.D.; Vleugels, J.; Kruth, J.; Van Humbeeck, J.; Vanmeensel, K. Mechanical and electrical properties of selective laser-melted parts produced from surface-oxidized copper powder. Mater. Des. Process. Commun. 2020, 2, e94. [CrossRef]

66. Rumpf, H. Die Wissenschaft des Agglomerierens. Chem. Ing. Tech. 1974, 46, 1-11. [CrossRef]

67. Lüddecke, A.; Pannitz, O.; Zetzener, H.; Sehrt, J.; Kwade, A. Powder properties and flowability measurements of tailored nanocomposites for powder bed fusion applications. Mater. Des. 2021, 202, 109536. [CrossRef]

68. Al-mangour, B. Powder metallurgy of stainless steel: State-of-the art, challenges, and development. In Stainless Steel; Pramanik, A., Basak, A.K., Eds.; Nova Science Publishers: Hauppauge, NY, USA, 2015; ISBN 9781634820806.

69. Gobber, F.; Bidulská, J.; Fais, A.; Bidulský, R.; Grande, M. Innovative Densification Process of a Fe-Cr-C Powder Metallurgy Steel. Metals 2021, 11, 665. [CrossRef]

70. Majumdar, J.D.; Kumar, A.; Li, L. Direct laser cladding of SiC dispersed AISI 316L stainless steel. Tribol. Int. 2009, 42, 750-753. [CrossRef]

71. Javanbakht, M.; Hadianfard, M.J.; Salahinejad, E. Microstructure and mechanical properties of a new group of nanocrystalline medical-grade stainless steels prepared by powder metallurgy. J. Alloys Compd. 2015, 624, 17-21. [CrossRef]

72. Tjong, S.; Lau, K. Sliding wear of stainless steel matrix composite reinforced with TiB2 particles. Mater. Lett. 1999, 41, 153-158. [CrossRef]

73. Peter, W.H.; Muth, T.; Chen, W.; Yamamoto, Y.; Jolly, B.; Stone, N.A.; Cantin, G.M.D.; Barnes, J.; Paliwal, M.; Smith, R.; et al. Titanium Sheet Fabricated from Powder for Industrial Applications. JOM 2012, 64, 566-571. [CrossRef]

74. Qin, Y.; Geng, L.; Ni, D. Dry sliding wear behavior of extruded titanium matrix composite reinforced by in situ TiB whisker and TiC particle. J. Mater. Sci. 2011, 46, 4980-4985. [CrossRef]

75. Ivasishin, O.M.; Anokhin, V.; Demidik, A.; Savvakin, D.G. Cost-Effective Blended Elemental Powder Metallurgy of Titanium Alloys for Transportation Application. Key Eng. Mater. 2000, 188, 55-62. [CrossRef]

76. Gerling, R.; Clemens, H.; Schimansky, F. Powder Metallurgical Processing of Intermetallic Gamma Titanium Aluminides. Adv. Eng. Mater. 2004, 6, 23-38. [CrossRef]

77. Yan, M.; Qian, M.; Kong, C.; Dargusch, M. Impacts of trace carbon on the microstructure of as-sintered biomedical Ti-15Mo alloy and reassessment of the maximum carbon limit. Acta Biomater. 2014, 10, 1014-1023. [CrossRef] [PubMed]

78. Kafkas, F.; Ebel, T. Metallurgical and mechanical properties of Ti-24Nb-4Zr-8Sn alloy fabricated by metal injection molding. $J$. Alloys Compd. 2014, 617, 359-366. [CrossRef]

79. Savalani, M.; Ng, C.; Li, Q.; Man, H. In situ formation of titanium carbide using titanium and carbon-nanotube powders by laser cladding. Appl. Surf. Sci. 2012, 258, 3173-3177. [CrossRef]

80. Kempen, K.; Thijs, L.; Van Humbeeck, J.; Kruth, J.-P. Mechanical Properties of AlSi10Mg Produced by Selective Laser Melting. Phys. Procedia 2012, 39, 439-446. [CrossRef]

81. Hirsch, J. Recent development in aluminium for automotive applications. Trans. Nonferrous Met. Soc. China 2014, $24,1995-2002$. [CrossRef]

82. Manfredi, D.; Bidulský, R. Laser powder bed fusion of aluminum alloys. Acta Met. Slovaca 2017, 23, 276-282. [CrossRef]

83. Chen, C.; Guo, L.; Luo, J.; Hao, J.; Guo, Z.; Volinsky, A.A. Aluminum powder size and microstructure effects on properties of boron nitride reinforced aluminum matrix composites fabricated by semi-solid powder metallurgy. Mater. Sci. Eng. A 2015, 646, 306-314. [CrossRef]

84. Vasanth, K.M.J.; Ram, P.L.; Anand, V.P.; Prabu, M.; Rahul, S. Experimental investigation of mechanical and tribological properties of Aluminium metal matrix composites fabricated by powder metallurgy route-A review. Mater. Today Proc. 2020, 33, 1058-1072. [CrossRef]

85. Casati, R.; Fiocchi, J.; Fabrizi, A.; Lecis, N.; Bonollo, F.; Vedani, M. Effect of ball milling on the ageing response of Al2618 composites reinforced with $\mathrm{SiC}$ and oxide nanoparticles. J. Alloys Compd. 2017, 693, 909-920. [CrossRef]

86. Tan, Q.; Zhang, J.; Mo, N.; Fan, Z.; Yin, Y.; Bermingham, M.; Liu, Y.; Huang, H.; Zhang, M.-X. A novel method to 3D-print fine-grained AlSi10Mg alloy with isotropic properties via inoculation with LaB6 nanoparticles. Addit. Manuf. 2020, $32,101034$. [CrossRef]

87. Li, P.; Tian, W.; Wang, D.; Liu, X. Grain refining potency of LaB6 on aluminum alloy. J. Rare Earths 2012, 30, 1172-1176. [CrossRef]

88. Liu, S.; Cui, C.; Wang, X.; Han, C.; Chen, H.; Shi, J. Interfacial microstructure and nucleating mechanism of melt-spun CeB $6 / \mathrm{Al}$ composite inoculant. Appl. Surf. Sci. 2018, 431, 202-206. [CrossRef]

89. Tran, T.Q.; Chinnappan, A.; Lee, J.K.Y.; Loc, N.H.; Tran, L.T.; Wang, G.; Kumar, V.V.; Jayathilaka, W.A.D.M.; Ji, D.; Doddamani, M.; et al. 3D Printing of Highly Pure Copper. Metals 2019, 9, 756. [CrossRef]

90. Constantin, L.; Wu, Z.; Li, N.; Fan, L.; Silvain, J.-F.; Lu, Y.F. Laser 3D printing of complex copper structures. Addit. Manuf. 2020, 35, 101268. [CrossRef]

91. Gobber, F.S.; Bidulská, J.; Fais, A.; Franchini, F.; Bidulský, R.; Kvačkaj, T.; Grande, M.A. Characterization of microstructural and mechanical properties after cold rolling of an electro-sinter-forged Cu-Sn alloy. Arch. Metall. Mater. 2020, 65, 787-792. [CrossRef]

92. Wu, S. Preparation of ultra-fine copper powder and its lead-free conductive thick film. Mater. Lett. 2007, 61, 3526-3530. [CrossRef] 
93. Tiberto, D.; Klotz, U.E.; Held, F.; Wolf, G. Additive manufacturing of copper alloys: Influence of process parameters and alloying elements. Mater. Sci. Technol. 2019, 35, 969-977. [CrossRef]

94. Naeem, M. Laser Processing of Reflective Materials. Laser Tech. J. 2013, 10, 18-20. [CrossRef]

95. Ikeshoji, T.-T.; Nakamura, K.; Yonehara, M.; Imai, K.; Kyogoku, H. Selective Laser Melting of Pure Copper. JOM 2018, 70, 396-400. [CrossRef]

96. Jadhav, S.; Dadbakhsh, S.; Goossens, L.; Kruth, J.-P.; Van Humbeeck, J.; Vanmeensel, K. Influence of selective laser melting process parameters on texture evolution in pure copper. J. Mater. Process. Technol. 2019, 270, 47-58. [CrossRef]

97. Mao, Z.; Zhang, D.Z.; Wei, P.; Zhang, K. Manufacturing Feasibility and Forming Properties of Cu-4Sn in Selective Laser Melting. Materials 2017, 10, 333. [CrossRef] [PubMed]

98. Scudino, S.; Unterdörfer, C.; Prashanth, K.; Attar, H.; Ellendt, N.; Uhlenwinkel, V.; Eckert, J. Additive manufacturing of Cu-10Sn bronze. Mater. Lett. 2015, 156, 202-204. [CrossRef]

99. Asano, K.; Tsukamoto, M.; Sechi, Y.; Sato, Y.; Masuno, S.-I.; Higashino, R.; Hara, T.; Sengoku, M.; Yoshida, M. Laser metal deposition of pure copper on stainless steel with blue and IR diode lasers. Opt. Laser Technol. 2018, 107, 291-296. [CrossRef]

100. Ehrenreich, H.; Philipp, H.R. Optical Properties of Ag and Cu. Phys. Rev. 1962, 128, 1622-1629. [CrossRef]

101. Wu, Z.; Liang, Y.; Fu, E.; Du, J.; Wang, P.; Fan, Y.; Zhao, Y. Effect of Ball Milling Parameters on the Refinement of Tungsten Powder. Metals 2018, 8, 281. [CrossRef]

102. Ghayour, H.; Abdellahi, M.; Bahmanpour, M. Optimization of the high energy ball-milling: Modeling and parametric study. Powder Technol. 2016, 291, 7-13. [CrossRef]

103. Toozandehjani, M.; Matori, K.A.; Ostovan, F.; Aziz, S.A.; Mamat, S. Effect of Milling Time on the Microstructure, Physical and Mechanical Properties of $\mathrm{Al}-\mathrm{Al}_{2} \mathrm{O}_{3}$ Nanocomposite Synthesized by Ball Milling and Powder Metallurgy. Materials 2017, $10,1232$. [CrossRef]

104. AlMangour, B.; Kim, Y.-K.; Grzesiak, D.; Lee, K.-A. Novel TiB2-reinforced 316L stainless steel nanocomposites with excellent roomand high-temperature yield strength developed by additive manufacturing. Compos. Part B Eng. 2019, 156, 51-63. [CrossRef]

105. Zhai, W.; Zhou, W.; Nai, S.M.L.; Wei, J. Characterization of nanoparticle mixed 316 L powder for additive manufacturing. J. Mater. Sci. Technol. 2020, 47, 162-168. [CrossRef]

106. AlMangour, B.; Grzesiak, D.; Borkar, T.; Yang, J.-M. Densification behavior, microstructural evolution, and mechanical properties of TiC/316L stainless steel nanocomposites fabricated by selective laser melting. Mater. Des. 2018, 138, 119-128. [CrossRef]

107. Gu, D.; Wang, H.; Dai, D.; Yuan, P.; Meiners, W.; Poprawe, R. Rapid fabrication of Al-based bulk-form nanocomposites with novel reinforcement and enhanced performance by selective laser melting. Scr. Mater. 2015, 96, 25-28. [CrossRef]

108. Li, W.; Yang, Y.; Liu, J.; Zhou, Y.; Li, M.; Wen, S.; Wei, Q.; Yan, C.; Shi, Y. Enhanced nanohardness and new insights into texture evolution and phase transformation of $\mathrm{TiAl} / \mathrm{TiB}_{2}$ in-situ metal matrix composites prepared via selective laser melting. Acta Mater. 2017, 136, 90-104. [CrossRef]

109. Gu, D.; Meng, G.; Li, C.; Meiners, W.; Poprawe, R. Selective laser melting of TiC/Ti bulk nanocomposites: Influence of nanoscale reinforcement. Scr. Mater. 2012, 67, 185-188. [CrossRef]

110. He, B.; Chang, K.; Wu, W.; Zhang, C. The formation mechanism of TiC reinforcement and improved tensile strength in additive manufactured Ti matrix nanocomposite. Vacuum 2017, 143, 23-27. [CrossRef]

111. Zhang, B.; Bi, G.; Nai, S.; Sun, C.-N.; Wei, J. Microhardness and microstructure evolution of $\mathrm{TiB}_{2}$ reinforced Inconel $625 / \mathrm{TiB}_{2}$ composite produced by selective laser melting. Opt. Laser Technol. 2016, 80, 186-195. [CrossRef]

112. Rong, T.; Gu, D.; Shi, Q.; Cao, S.; Xia, M. Effects of tailored gradient interface on wear properties of WC/Inconel 718 composites using selective laser melting. Surf. Coat. Technol. 2016, 307, 418-427. [CrossRef]

113. Rong, T.; Gu, D. Formation of novel graded interface and its function on mechanical properties of $\mathrm{WC}_{1-\mathrm{x}}$ reinforced Inconel 718 composites processed by selective laser melting. J. Alloys Compd. 2016, 680, 333-342. [CrossRef]

114. Wang, M.; Zhou, Z.; Sun, H.; Hu, H.; Li, S. Microstructural observation and tensile properties of ODS-304 austenitic steel. Mater. Sci. Eng. A 2013, 559, 287-292. [CrossRef]

115. Wang, M.; Sun, H.; Zou, L.; Zhang, G.; Li, S.; Zhou, Z. Structural evolution of oxide dispersion strengthened austenitic powders during mechanical alloying and subsequent consolidation. Powder Technol. 2015, 272, 309-315. [CrossRef]

116. Zhou, W.; Sun, X.; Kikuchi, K.; Nomura, N.; Yoshimi, K.; Kawasaki, A. Carbon nanotubes as a unique agent to fabricate nanoceramic/metal composite powders for additive manufacturing. Mater. Des. 2018, 137, 276-285. [CrossRef]

117. Koch, C.C. Intermetallic matrix composites prepared by mechanical alloying-A review. Mater. Sci. Eng. A 1998, $244,39-48$. [CrossRef]

118. Suryanarayana, C. Mechanical alloying and milling. Prog. Mater. Sci. 2001, 46, 1-184. [CrossRef]

119. Song, B.; Dong, S.; Coddet, C. Corrigendum to: 'Rapid in situ fabrication of Fe/SiC bulk nanocomposites by selective laser melting directly from a mixed powder of microsized Fe and SiC' [Scripta Materialia 75 (2014) 90-93]. Scr. Mater. 2020, $178,413$. [CrossRef]

120. Sudagar, J.; Lian, J.; Sha, W. Electroless nickel, alloy, composite and nano coatings-A critical review. J. Alloys Compd. 2013, 571, 183-204. [CrossRef]

121. Erfanmanesh, M.; Razavi, R.S.; Abdollah-Pour, H.; Mohammadian-Semnani, H. Influence of using electroless Ni-P coated WC-Co powder on laser cladding of stainless steel. Surf. Coat. Technol. 2018, 348, 41-54. [CrossRef] 
122. Li, Y.; Liu, R.; Zhang, J.; Luo, G.; Shen, Q.; Zhang, L. Fabrication and microstructure of W-Cu composites prepared from Ag-coated Cu powders by electroless plating. Surf. Coat. Technol. 2019, 361, 302-307. [CrossRef]

123. Xu, Q.; Zhu, X.; Cao, M.; Long, J. Preparation and properties of silver-coated copper powder with Sn transition layer. Mater. Res. Express 2019, 6, 076563. [CrossRef]

124. Güler, O.; Varol, T.; Alver, Ü.; Çanakçı, A. The effect of flake-like morphology on the coating properties of silver coated copper particles fabricated by electroless plating. J. Alloys Compd. 2019, 782, 679-688. [CrossRef]

125. Geng, K.; Yang, Y.; Li, S.; Misra, R.D.K.; Zhu, Q. A General Strategy for Enhancing 3D Printability of High Laser Reflectivity Pure Aluminum Powder. Met. Mater. Trans. A 2019, 50, 4970-4976. [CrossRef]

126. Geng, K.; Yang, Y.; Li, S.; Misra, R.; Zhu, Q. Enabling high-performance 3D printing of Al powder by decorating with high laser absorbing Co phase. Addit. Manuf. 2020, 32, 101012. [CrossRef]

127. Kupková, M.; Kupka, M.; Strobl, S.; Černý, M.; Khatibi, G.; Gierl, C. On a discrepancy in modulus of elasticity as determined from separate resonance frequencies of a bar sintered from copper-coated iron powder. Scr. Mater. 2007, 57, 639-642. [CrossRef]

128. Zhou, W.; Dong, M.; Zhou, Z.; Sun, X.; Kikuchi, K.; Nomura, N.; Kawasaki, A. In situ formation of uniformly dispersed Al4C3 nanorods during additive manufacturing of graphene oxide/ Al mixed powders. Carbon 2019, 141, 67-75. [CrossRef]

129. Cerbelaud, M.; Videcoq, A.; Abélard, P.; Pagnoux, C.; Rossignol, A.F.; Ferrando, R. Heteroaggregation between $\mathrm{Al}_{2} \mathrm{O}_{3} \mathrm{Submi}^{-}$ crometer Particles and $\mathrm{SiO}_{2}$ Nanoparticles: Experiment and Simulation. Langmuir 2008, 24, 3001-3008. [CrossRef] [PubMed]

130. Marzun, G.; Streich, C.; Jendrzej, S.; Barcikowski, S.; Wagener, P. Adsorption of Colloidal Platinum Nanoparticles to Supports: Charge Transfer and Effects of Electrostatic and Steric Interactions. Langmuir 2014, 30, 11928-11936. [CrossRef]

131. Wilms, M.B.; Streubel, R.; Frömel, F.; Weisheit, A.; Tenkamp, J.; Walther, F.; Barcikowski, S.; Schleifenbaum, J.H.; Gökce, B. Laser additive manufacturing of oxide dispersion strengthened steels using laser-generated nanoparticle-metal composite powders. Procedia CIRP 2018, 74, 196-200. [CrossRef]

132. Streubel, R.; Wilms, M.B.; Doñate-Buendía, C.; Weisheit, A.; Barcikowski, S.; Schleifenbaum, J.H.; Gökce, B. Depositing lasergenerated nanoparticles on powders for additive manufacturing of oxide dispersed strengthened alloy parts via laser metal deposition. Jpn. J. Appl. Phys. 2018, 57, 57. [CrossRef]

133. Doñate-Buendía, C.; Frömel, F.; Wilms, M.B.; Streubel, R.; Tenkamp, J.; Hupfeld, T.; Nachev, M.; Gökce, E.; Weisheit, A.; Barcikowski, S.; et al. Oxide dispersion-strengthened alloys generated by laser metal deposition of laser-generated nanoparticlemetal powder composites. Mater. Des. 2018, 154, 360-369. [CrossRef]

134. Zhang, Y.; Li, S.; Zhao, Y.; Duan, W.; Liu, B.; Wang, T.; Wang, G. Digital light processing 3D printing of AlSi10Mg powder modified by surface coating. Addit. Manuf. 2021, 39, 101897. [CrossRef]

135. Garmendia, X.; Chalker, S.; Bilton, M.; Sutcliffe, C.; Chalker, P. Microstructure and mechanical properties of Cu-modified AlSi10Mg fabricated by Laser-Powder Bed Fusion. Materials 2020, 9, 100590. [CrossRef]

136. Ma, C.; Chen, L.; Cao, C.; Li, X. Nanoparticle-induced unusual melting and solidification behaviours of metals. Nat. Commun. 2017, 8, 14178. [CrossRef]

137. Coguill, S.L.; Martineau, Z.R. Vessel Geometry and Fluid Properties Influencing Mix Behavior for ResonantAcoustic ${ }^{\circledR} M i x i n g$ Processes. In Proceedings of the 38th International Pyrotechnics Seminar, Denver, CO, USA, 10-15 June 2012; pp. 2-7. [CrossRef]

138. Monzón, M.; Ortega, Z.; Hernández, A.; Paz, R.; Ortega, F. Anisotropy of Photopolymer Parts Made by Digital Light Processing. Materials 2017, 10, 64. [CrossRef] [PubMed]

139. Wang, M.; Xie, C.; He, R.; Ding, G.; Zhang, K.; Wang, G.; Fang, D. Polymer-derived silicon nitride ceramics by digital light processing based additive manufacturing. J. Am. Ceram. Soc. 2019, 102, 5117-5126. [CrossRef]

140. Liu, H.; Ye, H.; Lin, T.; Zhou, T. Synthesis and characterization of PMMA $/ \mathrm{Al}_{2} \mathrm{O}_{3}$ composite particles by in situ emulsion polymerization. Particuology 2008, 6, 207-213. [CrossRef]

141. Babul, T.; Baranowski, M.; Sobczak, N.; Homa, M.; Leśniewski, W. Thermophysical Properties of Cu-Matrix Composites Manufactured Using Cu Powder Coated with Graphene. J. Mater. Eng. Perform. 2016, 25, 3146-3151. [CrossRef]

142. Danafar, F.; Fakhru'L-Razi, A.; Salleh, M.A.M.; Biak, D.R.A. Fluidized bed catalytic chemical vapor deposition synthesis of carbon nanotubes-A review. Chem. Eng. J. 2009, 155, 37-48. [CrossRef]

143. Li, S.F.; Liu, Y.; Yang, Y.F.; Zhu, Q.S.; Kondoh, K.; Misra, R.D.K.; Tan, C.; Hu, C.Q.; Ge, Y. Activating Trace Fe Impurity as Catalyst to Plant Carbon Nanotubes Within Ti-6Al-4V Powders for High-Performance Ti Metal Matrix Composites. Met. Mater. Trans. A 2019, 50, 3975-3979. [CrossRef]

144. Geng, K.; Li, S.; Yang, Y.; Misra, R. 3D printing of Al matrix composites through in situ impregnation of carbon nanotubes on $\mathrm{Al}$ powder. Carbon 2020, 162, 465-474. [CrossRef]

145. Sachs, M.; Hentschel, O.; Schmidt, J.; Karg, M.; Schmidt, M.; Wirth, K.-E. Production of Al/Cu-Particles and their Potential for Processing by Laser Beam Melting (LBM). Phys. Procedia 2014, 56, 125-134. [CrossRef]

146. Pannitz, O.; Lüddecke, A.; Kwade, A.; Sehrt, J. Investigation of the in situ thermal conductivity and absorption behavior of nanocomposite powder materials in laser powder bed fusion processes. Mater. Des. 2021, 201, 109530. [CrossRef]

147. Matos, M.; Castanho, J.M.; Vieira, M.T. Composite copper/stainless steel coated powders. J. Alloys Compd. 2009, 483, 460-463. [CrossRef]

148. Fernandes, C.; Senos, A.; Vieira, M. Particle surface properties of stainless steel-coated tungsten carbide powders. Powder Technol. 2006, 164, 124-129. [CrossRef] 
149. Simões, F.; Duarte, N.; Trindade, B. Sinterability of mechanically alloyed Ti-37.5Si (at.\%) powders coated with a metallic thin layer by sputtering. Rev. Adv. Mater. Sci. 2008, 18, 293-296.

150. Fernandes, C.; Senos, A.; Vieira, M.; Antunes, J. Mechanical characterization of composites prepared from WC powders coated with Ni rich binders. Int. J. Refract. Met. Hard Mater. 2008, 26, 491-498. [CrossRef]

151. Jadhav, S.D.; Dadbakhsh, S.; Vanmeensel, K.; Kruth, J.-P. Copper, Gold, or Silver Powder for Powder Bed Additive Manufacturing and Method of Manufacturing Such Powder. Patent No. WO 2020/099662 A1, 22 May 2020.

152. Jadhav, S.D.; Dhekne, P.P.; Brodu, E.; Van Hooreweder, B.; Dadbakhsh, S.; Kruth, J.-P.; Van Humbeeck, J.; Vanmeensel, K. Laser powder bed fusion additive manufacturing of highly conductive parts made of optically absorptive carburized CuCr1 powder. Mater. Des. 2021, 198, 109369. [CrossRef] 